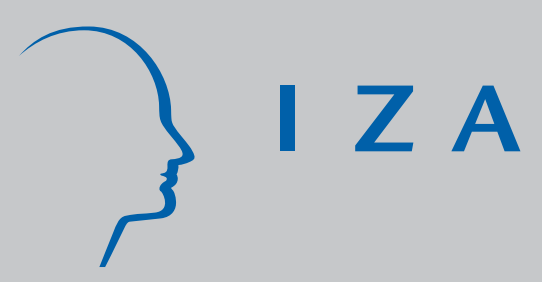

IZA DP No. 2298

First and Second Generation Immigrant Educational Attainment and Labor Market Outcomes: A Comparison of the United States and Canada

Abdurrahman Aydemir Arthur Sweetman 


\title{
First and Second Generation Immigrant Educational Attainment and Labor Market Outcomes: A Comparison of the United States and Canada
}

\author{
Abdurrahman Aydemir \\ Statistics Canada \\ Arthur Sweetman \\ Queen's University \\ and IZA Bonn
}

Discussion Paper No. 2298

September 2006

IZA

P.O. Box 7240

53072 Bonn

Germany

Phone: +49-228-3894-0

Fax: +49-228-3894-180

Email: iza@iza.org

Any opinions expressed here are those of the author(s) and not those of the institute. Research disseminated by IZA may include views on policy, but the institute itself takes no institutional policy positions.

The Institute for the Study of Labor (IZA) in Bonn is a local and virtual international research center and a place of communication between science, politics and business. IZA is an independent nonprofit company supported by Deutsche Post World Net. The center is associated with the University of Bonn and offers a stimulating research environment through its research networks, research support, and visitors and doctoral programs. IZA engages in (i) original and internationally competitive research in all fields of labor economics, (ii) development of policy concepts, and (iii) dissemination of research results and concepts to the interested public.

IZA Discussion Papers often represent preliminary work and are circulated to encourage discussion. Citation of such a paper should account for its provisional character. A revised version may be available directly from the author. 


\section{ABSTRACT \\ First and Second Generation Immigrant Educational Attainment and Labor Market Outcomes: A Comparison of the United States and Canada*}

The educational and labor market outcomes of the first, first-and-a-half, second and third generations of immigrants to the United States and Canada are compared. These countries' immigration flows have large differences in source countries, scale and timing, and Canada has a much larger policy emphasis on skilled workers. Following from these, the educational attainment of US immigrants is currently lower than that in Canada and the intergenerational transmission of education is expected to cause the gap to grow. This in turn influences earnings. Controlling only for age, the current US second generation has earnings comparable to those of the third, while earnings are higher for the second generation in Canada. Interestingly, the positive wage gap in favour of first-and-a-half and second generation immigrants in Canada is exceeded by the gap in educational attainment, but a lower immigrant rate of return attenuates education's impact. Moreover, observable characteristics explain little of the difference in earnings outcomes across generations in the US but their introduction into an earnings equation causes the Canadian second generation premium to switch signs and become negative relative to the third.

JEL Classification: J61, J62, I29

Keywords: immigration, second generation, Canada, United States, education

Corresponding author:

Arthur Sweetman

Queen's University

School of Policy Studies

Kingston ON K7L 3N6

Canada

E-mail: arthur.sweetman@queensu.ca

\footnotetext{
* Thanks for comments to Carmel U. Chiswick, Barry Chiswick and the participants at the Conference on Immigration Trends, Consequences and Prospects for the United States Sponsored by Smith Richardson Foundation. This paper is under submission for a special issue of Research in Labor Economics following from the conference.
} 


\section{Introduction}

Immigration-related educational and labor market outcomes depend upon selection, settlement, and related policy and practice over long stretches of time. In this context, comparing across countries can be useful in considering the relationship between policies and outcomes, and can point to factors that are more, and less, strongly affected by alternative choices. This comparison of the United States (US) and Canada looking at immigrants, the second generation, and generation one-and-a-half (those who immigrated as children), will lay out the relevant basic empirical regularities for the two countries in a comparable manner. It addresses the fundamental questions: How do the children of immigrants, and immigrants themselves, fare in North America? And, what links can we make between the observed outcomes and a country's policy choices? Of course, it is difficult to separate out the effects of policy in contrast to the effects of, for example, geography (e.g., the US’s proximity to Mexico), scale and international host country reputation effects, so some conclusions must remain tentative. Nevertheless, a comparison allows some sense of what alternative paths can imply for educational and labor market outcomes.

The country pairing is interesting since the US and Canada pursued broadly similar immigration policies prior to the 1960s using national origin, with an emphasis on northwestern Europe, to allocate immigration visas. In the 1960s, both countries dramatically altered their national immigration policies, and immigration patterns changed very substantially in the subsequent decades. Smith and Edmonston (1997, chap. 2) provide a brief overview of US immigration history, as do Green and Green (2004) for Canada. See the references in each for other studies. Overall, the two countries, partly by policy design and partly because of geography and other factors, took divergent paths. Four differences are particularly relevant: 1) the immigration rate, 2) the distribution of source countries, 3) the selection mechanism, and 4) settlement policies and practices.

Looking briefly at each of these four areas in turn, it is clear, first, that immigration rates differed markedly across the two countries for much of the last four or five decades, with the US having a much lower one as can be seen in Figure $1 .{ }^{1}$ However, the actual number of immigrants

\footnotetext{
${ }^{1}$ Note that illegal immigration is a much more important issue in the US than in Canada. The broad trends mentioned here are generally appropriate whether or not illegal immigration is taken into account, although
} 
to the US is much larger in absolute terms. The US population is about 9.2 times greater than the Canadian one, whereas in 2004 the US immigration intake was about four, and in 1970 it was only about 2.5, times greater. Thus, while the immigration rates of both countries have increased, and the US rate has increased faster, the US rate is still far below the Canadian one. It is also clear from Figure 1 that, in contrast to that in the US, Canada pursued a strongly pro-cyclical immigration policy prior to 1990. (Both also have spikes not associated with the cycle; especially, the Hungarian refugee movement for Canada, and the regularization in the late 1980s and early 1990s for the US.)

Second, changes in the distribution of source countries have affected both countries since, in the 1960s, each removed many regulatory and legislative criteria that discriminated against potential immigrants on the basis of race and ethnicity. In the years that followed, the source country mix changed very substantially. In particular, immigration from Europe declined in relative importance for both countries. However, great differences between the two countries also exist because of geography. The United States has always had a much greater fraction of its immigrant stream arriving from Central and South America (including Cuba), and Mexico, whereas Canada traditionally received a greater proportion of its immigrants from Europe. After the 1960s, the share of US immigrants from the abovementioned US source countries, and from Asian countries, grew in importance, while Europe became even less important. For Canada, the increase in the immigration rate from Asia was much more pronounced, and the decline in European immigration was proportionately smaller and regionally more concentrated. While the immigration rate to Canada from North-West Europe dropped very substantially, that from Eastern and Southern Europe, though fluctuating across periods, reduced much more modestly.

Third, as is well known, the US has largely favored family reunification as the main immigration stream. By contrast, while Canada maintained a family class, in 1967 Canada introduced a "points system” for skilled workers, within a parallel “economic” immigration class and developed an administratively complex immigration policy that sought to maximize domestic national interests while fulfilling the country's humanitarian and other related duties. Although there are subcategories that altered over time, Canadian immigration comprises three main classes that have endured: economic, family, and humanitarian. While this is an important 
difference, it can also be overstated since, for example, in 2004 the economic class comprised an historical extreme at $54.7 \%$ of all immigration, which includes refugees (more typically the economic class has comprised 30 to 40 percent of the flow for the past few decades). But, principal applicant skilled workers, most commonly the male of each family, assessed under the points system still only accounted for $20.3 \%$ of the entire flow (Citizenship and Immigration Canada, 2005).

Finally, settlement and related policies differ very substantially across the two countries, as do the nations' self-perceptions, and this may have important impacts for the second generation. Tellingly, in 1971 Canada became the first country to adopt an official “multiculturalism policy”, and in 1982 the nation's multicultural heritage was recognized in the then new Canadian Charter of Rights and Freedoms, which forms part of the Constitution. This is a symbol of an approach that contrasts with that in the US and may have implications for settlement issues including educational and economic integration both for new immigrants and across the generations. However, the exact nature of the impact is ambiguous. For example, multiculturalism could imply increased retention of ethnic norms, including, for example, maintaining differences in educational attainment. Or, it could imply greater effort at social and economic inclusion leading to faster integration. Of course, alternative elements of the diverse range of settlement policies and services, and national attitudes, could have impacts in different directions. Hence, while we have no strong predictions, settlement patterns and policies are worth bearing in mind since they clearly differ across the two countries and are particularly relevant to the second generation. Of course, the current second generation are partly the children of a previous generation of immigrants who landed as these policies started coming into force, and future second generations will have a different experience.

Together, these four important differences are associated with substantial differences in average immigrant education and earnings, but, perhaps surprisingly, there nevertheless remain many similarities. This paper seeks to identify and explore both the differences and similarities in outcomes, with the goal of learning more from the comparison than would be possible by studying either country in isolation. A broad descriptive overview is provided that examines the data on several dimensions, especially sex, country, and immigration status. The paper proceeds as follows. First the data is presented and then descriptive statistics are presented to gain a broad understanding of the current state of each jurisdiction. The first set of descriptive statistics 
combine the two sexes and look at broad generational issues for the entire prime age population irrespective of labor force attachment, then the analysis explores results by sex and country, and looks at educational and labor market outcomes. Next, regression analysis is used to explore first, educational attainment, and then annual earnings. A conclusion reviews the main findings and attempts to integrate various observations.

\section{Data}

For both countries, the sample is restricted to those between the ages of 25 and 65, inclusive, but very few other restrictions are imposed. Country-specific issues are discussed below. Initially, the entire sample is used to generate descriptive statistics without regard to labor force attachment; subsequently, in focusing on wages, all those who are in the labor force and who are not in school are analyzed. We are interested in maintaining as comprehensive a sample as possible to reflect the entire population of immigrants and not a selected sub-sample, such as those who work full-time full-year. To that end we include in our earnings analysis all those who are in the labor force, and, for the small group who have zero earnings in the survey year, we set their earnings to one dollar. In looking at educational and labor market outcomes relevant to immigration policy it is important to address the entire population, and not only those who have earnings. However, we do not go so far as to include those not in the labor force in studying earnings. Selected sensitivity analyses show that this tends to accentuate some of the negative immigrant coefficients, but has no substantive impact on the patterns of the findings. Note that, or particular relevance for women, there is no attempt to adjust for selectivity into the labor force, rather the sample is based on the observed status in the survey year.

\subsection{United States}

Seven merged CPS March supplements, from 1998 to 2004, are used to provide insight into outcomes in the US. However, a major reduction in the sample size is made to eliminate all second interviews. As noted by Card, DiNardo and Estes (2000, footnote 9) in a closely related 
study, if the entire sample is retained, the standard errors are incorrect, being about $17 \%$ too small and thus inference is difficult. Correcting the standard errors is also problematic given the information provided in the CPS. Hence, we only use records reporting that the interview is from one of the first four months (as opposed to the second four), so there are no replicated individuals in our merged sample.

Also excluded from the sample are first or second generation observations who report that they or their parents were born in American Samoa, Guam, Puerto Rico or the U.S. Virgin Islands. Though relatively small in number, these individuals introduce heterogeneity into the sample, whereas a tighter unit of analysis is desired for this analysis. The classification of race in the March CPS alters in 2003 allowing for mixed race to be reported. To maintain consistency for analysis, we attempt to code all observations in the limited categories used in the first period of the sample: White, Black, American Indian, and the merged group Asian and Pacific Islander. ${ }^{2}$ We code those who report mixed race into the minority group of the mixed group, and randomly assign individuals who report two minority groups. This is clearly not ideal, but affects only a tiny fraction of the sample and does not appear to appreciably affect the results. The process is facilitated by our merging the Asian and Pacific Islander groups. Survey weights are used throughout the analysis.

\subsection{Canada}

The analysis for Canada uses the 2001 Canadian Census individual 20\% micro data file, and to reduce computer processing time a 1 in 4 random sample is used. A new question was added to the 2001 Canadian Census referring to the birthplace of the respondent's parents allowing the identification of second generation immigrants. This marks the first time since 1971 that second generation immigrants can be identified in Canadian census files. We exclude from the sample individuals who are living in institutions. The 2001 census also allows identification of temporary residents -- which refers to people from another country who had an employment or student authorization, or a Minister's permit, or who were being processed as refugee claimants at the time of the census -- and their family members living in Canada. Although the

\footnotetext{
${ }^{2}$ We use the terminology and classification system of the pre-2003 CPS files in much of the remainder of the paper.
} 
US data likely contains some temporary residents, we remove them from the Canadian data and restrict the sample to consist of Canadian-citizens by birth and immigrants. This latter group consists of naturalized citizens and permanent residents.

The visible minority question in the Canadian Census allows identification of Blacks, Asians and Aboriginals. For identification of Aboriginals we also use the separate question of “registered Indian” since not all registered Indians identify themselves as an Aboriginal ethnic minority. The remaining visible minority categories include Latin American, Arab, multiple visible minorities, and the "other" category which captures non-visible minorities. CPS definitions classify those from the Middle East as White. As a result the non-visible minority ("White”) group consists of non-Black, non-Asian and non-Aboriginals. A separate question on ethnic origin allows identification of Hispanics, and, as with the US data, Hispanic is classified independently of the other ethnic affiliations. The sampling weights provided for the 2001 Census are used throughout.

\section{Descriptive Statistics}

Initially, the paper describes the distribution and demographic characteristics of the populations of the two countries, separately identifying immigrants, and the second and third generations. This is presented for the entire sample, regardless of labor force attachment, and does not distinguish by sex in the results presented since an examination of the results by sex showed virtually no differences on this dimension. Descriptive statistics looking at educational and labor market outcomes, by sex, follow.

Each of the main groupings -- immigrant, second generation (i.e., those born in the country with at least one parent born outside) and third generation (i.e., both parents born in the country) -- is also divided into sub-groups as discussed below. However, the treatment of the third generation is worth discussing at this point. One issue in the cross-country analysis is defining a suitably homogeneous comparison group. Normally, the third generation is taken to be this group, but this generation is sufficiently different across the two countries that we divide it into two: first, "third generation type I" a homogeneous majority grouping of those who are nonHispanic, non-Aboriginal (classified as American Indian in the CPS), non-visible minority 
(classified as White in the CPS) who were not born abroad, and, second, "third generation type II", which is the complement of the first. The second group is included in the initial descriptive statistics for completeness, but omitted from the remainder of the paper since this group is not the focus of the analysis.

None of the tables of descriptive statistics present standard errors. This is done primarily to conserve space; the sample sizes are quite large so that the means are estimated very precisely.

\subsection{Immigration Status and Demographics for the Entire Population}

Table 1 presents each generation's share of the population, and the result of the US and Canada having taken different trajectories with respect to immigration rates is immediately apparent. Immigrants comprise an eight percent smaller share of the population in the US than in Canada. The difference in the share of the population that is second generation is similarly large. Although retention rates (emigration and mortality rates) and, for the second and third generations, fertility rates also play a role, the evidence supports Canada having had a much higher rate of immigration than the US. It is worth noting that, for both countries, the share of the population that are immigrants is much larger than is the share that is second generation. This reflects the increase in immigration rates in the last two or three decades. The difference is particularly striking once one considers that the second generation includes the multiple children of families with either one or two immigrant parents. If immigration rates matter for integration, then recent cohorts face a very different environment from earlier ones.

Despite the presence of both more immigrants and second generation immigrants in Canada, there is only a 3.6\% difference in the share that is third generation type I (that is, domestically born non-visible minority individuals). Of course, the converse is true of the third generation type II (those born abroad or members of a visible minority); this group is much larger in the US. Further, the third generation in the US is much more heterogeneous than that in Canada, as will be seen in more detail in table 4 .

The immigrant and second-generations groupings are subdivided in table 2. Given the literature on age arrival (e.g., Friedberg, 1993; Borjas, 1995; Chiswick and DebBurman, 2003; Schaafsma and Sweetman, 2001), we separate immigrants into those who landed by age 11 and 
earlier, or age 12 and later. Those who land earlier in their lives appear to have somewhat better outcomes, almost certainly complete their education in the host country, and have outcomes that are more similar to the native born. ${ }^{3}$ Second generation observations are categorized depending upon whether the father only, or mother only, or both parents, were immigrants. The first row for each country reports what percentage of the entire population is comprised by each sub-group, and the second row describes the percentage of the relevant major group (e.g., immigrants) comprised by each sub-group (e.g., immigrants who land by age 11). Interestingly, the relative size of the two immigrant sub-groups is quite similar despite a substantially larger share of the total population falling into each sub-group in Canada. The second generation, however, display a marked difference. The Canadian second generation is much less likely to have been born in a household with an immigrant mother and more likely to have both parents immigrants. If intermarriage among the generations is important for social and economic outcomes, for communities as well as individuals, this may have implications for integration.

Table 3 explores the regional origins of immigrants, and the parents of the second generation. Given the constraints of both countries’ data sources and our desire for comparability, we employ 13 regional categories, as well as each host country. Mexico is singled out given its importance in US immigration, and we construct a non-regional amalgam (non-UK, English, developed countries) comprising non-European English speaking developed countries (esp., Canada/the US as appropriate, Australia, New Zealand, and Barbados) since individuals from these countries share language and cultural traits.

Massive differences in the distribution of each generation across the source regions are evident in table 3 . Almost 30\% of immigrants to the US are from Mexico, whereas less than one percent of Canadian immigrants derive from there. Conversely, the rate of immigration from North West Europe is almost three times higher in Canada than the US, and that from Eastern Europe is about twice as high. Asian and African immigration is also much more common in Canada. Among the second generation with only one immigrant parent, in columns two and three, note that the first row in each of these columns matches the results in table 2 . The differences between the first, and second and third, columns partly reflect changes in source countries across the decades. Although still very important, the magnitude of Mexico’s

\footnotetext{
${ }^{3}$ Fry and Lowell (2005), however, do not find that US Latinos who arrive young have wage outcomes that are comparable to their US counterparts.
} 
contribution to the immigration flow among the second US generation is about half of what it is among the first. Notice that some regions, especially Asia, show a substantial increase in their share of immigrants to both countries for the more recent, first, generation. Europe, particularly North West Europe, has the opposite trend. Overall, as has been noted before by, especially, Borjas (1993), the distribution of immigrants across source countries is dramatically different in Canada and the US. This, of course, is potentially an important source of differences in outcomes.

Columns four and five of table 3 show the probability that both parents are immigrants given the father's and mother's source region. For both Canada and the US, individuals from the amalgam group of non-UK (or non-European), English speaking developed countries have a substantially lower chance of marrying an immigrant -- around 25 or 30\%. Those from northwest Europe have the next highest probability, and some groups, especially in Canada, have relatively high probabilities of marrying an immigrant rather than a native. For many groups, the probability of intermarriage (i.e., marrying a native born individual) is much lower in Canada. If intermarriage is an important measure of ethnic integration, then there are large differences across both regional source country groupings and host countries. The final, sixth, column catalogues the probability that members of each region origin sub-group with both parents immigrants have both parents from the same region. (Columns four and five indicate the likelihood that both parents are immigrants among the entire second generation, whereas column six reports the likelihood of both parents being from the same region among those who have both parents immigrants.) Clearly, if both parents are immigrants, the probability of them being from the same region is quite high, although, once again, it is lowest for those from the non-UK, English speaking developed region. Clearly, the regional pairing of parents can affect their children's outcomes and there are substantial differences across both countries and regions.

Basic descriptive statistics of selected demographic variables are presented in table 4 for each of the seven sub-groups. A few findings are worth highlighting. First, the percentage that are married is higher in the US than Canada for all groups except those who immigrated later in life, and the second generation marriage rates appear to be closer to those of the native born than are those of new immigrants in both countries. Within countries, marital status differs significantly across the groups, with immigrants who arrive at age 12 or older, and the third generation type I in the US, being much more likely to be currently married than the other 
groups. Also, there are clearly important differences in the ethnic makeup of the two countries. Recall that while the White, Black, American Indian (commonly called Aboriginal or First Nations in Canada), and Asian and Pacific Islander groups are mutually exclusive and exhaustive, the Hispanic category is independent and may have members in all of the other categories. The US has a far larger Hispanic population in all of the sub-groups, and among the third generation. The third generation type II group also differs dramatically across the countries. North American Indians, or Aboriginals, represent about 7\% of the sub-group in the US, but just over $83 \%$ in Canada. Conversely, the Black group is $72 \%$ of the US sub-group, but only $6.3 \%$ of that in Canada.

An interesting observation is that many of the second generation in the US, but far fewer in Canada, and a number of the third, are, in fact, not born in the host country. This is particularly the case where second generation status is because the mother, and not the father, is an immigrant. Since we have no data on when these individuals moved to the US or Canada, this adds a wrinkle to interpreting what it means to have local information, which is usually assumed for the second and third generation. For this reason, as mentioned, we have excluded those born abroad from our third generation main comparison group (i.e., they are in the type II group).

While we can only speculate as to the reasons for the cross-country difference, it might well have to do with the proportionately much larger US military presence around the globe.

\subsection{Educational Outcomes}

Educational outcomes for the sub-groups of interest, as well as for each sex separately, are summarized in Tables 5 and 6. Table 5 presents mean years of schooling, and shows that third generation type 1 Canadians have, on average, about half a year less schooling than their US counterparts. The gap is even bigger for the type II third generation (in the column labeled “other”). This lower Canadian base will influence all the comparisons.

Immigrants to the US of both sexes who arrive older than age 12 have fewer years of schooling than immigrants to Canada. One particularly interesting pattern is observable that aligns with cross-country policy differences regarding selection: among immigrants who arrive at an older age in Canada, but not in the US, on average males have appreciably more schooling 
than females. This aligns with the operation of the Canadian points system. It only looks at the education of the one adult that each family designates, most commonly the male. These differences are interesting and quantitatively quite important.

Focusing on the immigrants who land before age 11, in the two countries those who land younger have higher mean education levels than those who land at an older age. In the US, however, this number is in between the mean attainment of the native born and the mean for those who immigrate older, whereas in Canada those who land younger have substantially greater years of education than both. This suggests that what might be called integration, or at least achievement, is remarkably strong in Canada. Those who land young have remarkably high levels of educational attainment in Canada. This is likely attributable to multiple causes, but multiculturalism/settlement policy and practice, the distribution of source countries, and the selection system are likely all involved. At a minimum it speaks to the operation of each country’s education system.

For both sexes, second generation immigrants have greater mean levels of education in the US than do immigrants. This is particularly the case compared to immigrants who arrive after age 12, which is the much more numerous group. Further, second generation males in the US, and both sexes in Canada, also have greater levels of achievement than do the third generation; the numbers are more similar for US females. Perhaps surprisingly, in Canada, for both sexes, second generation observations where both parents are immigrants have particularly high levels of education, whereas this is not the case in the US. This might be related to the very high levels of attainment of immigrants who land young. It might also be associated with the previously observed greater propensity for the Canadian second generation parents not to intermarry with the third generation. The gaps in Canada are more pronounced given the lower level of educational attainment of the third generation. It appears that immigrants, especially those without third generation parents, have extremely good educational attainment in the Canadian school system.

The simple measure of years of schooling is expanded, in table 6, to explore the highest level of educational attainment. This table is quite revealing. In general, among the second and third generations there is a much greater prevalence of associate (or community college) degrees in Canada, reflecting differences in the two countries' educational investment and institutional structure with Canada’s post-secondary non-university system being much larger and its 
university system being somewhat smaller. Perhaps surprisingly, a similar pattern can also be seen among immigrants who arrive beyond age 12. This might reflect, at least in part, the operation of the Canadian points system, but it could also reflect differences in how source country equivalencies are interpreted. Generally, immigrants are more likely to be in both tails of the education distribution.

Completing high school is much more common in the US for both the second and third generation, but not among immigrants. The low number of years of school in the US for immigrants is largely due to a large number of individuals with very low levels of schooling -less than 8 completed years. The finding that the second generation has, relative to the third generation type I comparison group, better educational outcomes in Canada is seen again. Part of this is because Canada has a relatively large proportion of the third generation with incomplete high school, and with an associate's rather than a university, degree. Although not shown here, a preponderance of the third generation type I with low education in Canada are at the upper end of the age distribution.

\subsection{Labor Market Outcomes}

Labor force attachment in the survey week and related outcomes are addressed in table 7. ${ }^{4}$ In these data annual earnings capture all employment and positive self-employment earnings in the year. For the US data, the numbers are adjusted to 2000 dollars using the CPI. However, the Canadian earnings data are not adjusted using an exchange rate to make their levels comparable with US earnings; this was not thought necessary since most of our results are from regressions using log wages and we focus on percentage changes. But, since the CPS earnings data are capped, a similar cap is imposed on the Canadian data using purchasing power parity exchange rates to establish the line.

For males and Canadian females, the most disadvantaged group in both countries appears to be neither immigrants nor the second generation, but the third generation II sub-group. ${ }^{5}$

\footnotetext{
${ }^{4}$ Note that Canada and the US employ different definitions of the unemployment rate, with the US definition producing a slightly lower rate when applied to the same population as the Canadian one.

${ }^{5}$ Note that the tax regime faced by many American Indians/Aboriginals differs from the rest of the population, making many earnings related comparisons difficult.
} 
Broadly speaking, similar patterns to those seen for educational attainment can be observed for these labor market outcomes. Just as the US third generation had greater years of schooling than their Canadian counterparts, they have greater weeks of work and related outcomes. However, immigrant males in the US have very high employment rates compared to all other groups despite their educational disadvantages. Further, immigrant women who land older have relatively poorer outcomes compared to their male counterparts (using the third generation type I as a benchmark for both). In particular, they are markedly more likely to be out of the labor force. Perhaps migration is primarily driven by male job seeking and their partners' job matches are not as successful following the transition.

In Canada, but not to nearly the same degree in the US, immigrants who land young, have extremely good labor market outcomes. The second generation do very well in both countries, with averages that are at or slightly above the third generation ones for the US, and markedly above in Canada. The second generation appears to have relatively better outcomes in general in Canada. One group worth remarking upon is the second generation subgroup with both parents immigrants. For both sexes in the US this group fares more poorly on average, whereas in Canada they have very high levels of achievement. The nature of this group and/or its reception into society clearly differs markedly in the two countries.

\section{Regression Results}

Two sets of regressions are pursued in what follows: first, those where the dependent variable is years of schooling, and, second, those where it is (the logarithm of) annual earnings. Multivariate analysis is particularly useful in this context since there are major differences in age, ethnic and source country compositions across the two host countries, and some differences in urban concentration, marital status and the like. This will allow us to explore whether the observed differences across countries is primarily the result of composition, or if other factors are at work. In the education regressions the sample is the same as that in the descriptive statistics with two exceptions: those currently attending school full time, and the third generation II group, are omitted. A further restriction is made for the earnings regressions and those not in the labor force are eliminated from the sample. Observations who are in the labor force, but who 
report zero annual earnings are assigned an income of one dollar to permit the logarithmic transformation. Depending upon the research question being posed, it is sometimes the case that the sample for analysis with respect to earnings is best restricted to those with a high level of labor force attachment. For example, Baker and Benjamin (1994) exclude those who work less than 40 weeks in the survey year. However, in this case we wish to consider the outcomes of immigrants as a whole and, therefore, we want to cast the net as wide as is feasible in specifying our sample. We think that our broader sample is more appropriate to our empirical questions, and provides a better reflection of the entire immigrant labor force. This difference in approach is not innocuous. ${ }^{6}$

\subsection{Education Regressions}

Tables 8a, for males, and 8b, for females, present results of estimates from regressions of the form:

(1)

$$
S=b_{o}+b_{g} \text { Gen }+b_{A} \text { Age }+\left[b_{y r} \text { Year }\right]+\left\{b_{E} \text { Ethnicity }+b_{M} \text { MaritalStatus }+b_{C} \text { City }\right\}+\varepsilon
$$

Where $S$ is years of schooling, the b's are vectors of coefficients to be estimated and $\varepsilon$ is a white noise error term. The term in square brackets is only employed in the US data, and the terms in braces are used optionally in some regressions. The variables are clustered into related sets, the detailed contents of which are mentioned in table 8, having the following general descriptions: Gen is a vector of generational indicators; ${ }^{7}$ Age is a fourth order polynomial in age where the estimates are not presented to save space; Year, employed only for the US CPS data, is a set of six year indicators reflecting the underlying merged set of March supplements and is also not

\footnotetext{
${ }^{6}$ Some researchers might prefer a two step approach first looking at the probability of participation beyond some specified threshold such as 40 weeks of work per year, and then looking at the labor market outcomes of those beyond the threshold. Although there is great merit in this approach, we prefer to look at the sample of those who are in the labor force, regardless of earnings or weeks worked, since we think that this is an important group. A preliminary analysis suggests that the results presented in this paper are broadly similar to one with a sample with greater attachment, but that the findings are more extreme since groups with low earnings also appear to have a higher likelihood of being unemployed.

${ }^{7}$ Recall that the third generation type II group is always omitted from the regressions and, therefore, to simplify the exposition, we will simply refer to the comparison group or the third generation in discussing the regressions.
} 
presented to save space; Ethnicity; Marital Status and City are sets of indicators, as discussed in table 4, that are employed in some regressions.

The first and fourth columns in tables $8 \mathrm{~A}$ and $8 \mathrm{~B}$ describe differences in years of schooling controlling for age. Patterns similar to those seen in table 5 are apparent, but they are somewhat clearer with controls added. In the United States, immigrants of both sexes have fewer years of schooling than the native-born White population, with those who arrive young having at least a full year more schooling than those who arrive later in life. In stark contrast, immigrants to Canada have more years of education than the third generation, especially among the males. Clearly, the immigrant population of the two countries is quite different.

Individuals in the second generation, in contrast, have at least as many years of schooling as the third generation in the US, with males having somewhat larger gaps than females - up to about $40 \%$ of a year. A similar pattern is observed for Canada, but the magnitudes differ, with the second generation having a relatively greater gap relative to the third generation, and that for males and females being more similar. Immigrants and the second generation in Canada appear to be much more successful in the education system.

Controls for ethnicity are added in the second and fifth columns. Note that the comparison group (third generation type I) comprises only those who report being non-Hispanic and "White" in the CPS (and the equivalent in the Canadian data), and, therefore, has all of the ethnicity regression indicators set to zero. Hence the ethnic indicators are only set to one for a subset of those who are first or second generation immigrants. The change in the generational indicators' coefficients between specification 1 and 2 is pronounced for the US, but in dramatic contrast, has little impact for Canada. For example, US males who immigrate at age 11 or younger go from having half a year less schooling to having $85 \%$ of a year more than the third generation. The second generation has even larger positive gaps relative to the comparison group. The coefficients on the ethnic indicators, of course, explain why this is happening. Most importantly, the Hispanic indicator is massively negative, suggesting that Hispanics have, on average, three to three and a half fewer years of schooling, which is a very substantial gap. Since the Hispanic category is dominated by individuals from Mexico, among immigrants and the second generation much of this educational effect is attributable to the low levels of education of immigrants from that source country. In contrast, the American Indian coefficient is effectively zero, indicating that they have the same average level of schooling as the third generation; the 
Asian / Pacific Islander group have a positive coefficient; and the Black one is somewhat negative. Note also the differences in the increases in the R-squared values across countries; ethnicity is clearly a more important determinant of wages in the US.

The Canadian coefficients tell a very different story. The generational coefficients change relatively little for the most part, while the ethnic variables have two important differences compared to the US case. First, the coefficient on the Hispanic indicator is much smaller (and affects a much smaller fraction of the population, as seen in table 4), and second, the Aboriginal indicator is large and negative suggesting that this group is much more educationally disadvantaged in Canada than in the US. Moreover, the Black as well as the Asian/ Pacific Islander coefficients are positive in Canada. Clearly, ethnic group educational outcomes do not have the same patterns in the two countries.

Finally, in columns three and six, controls for marital status (never married being the omitted group) and urban status are added. Blau and Kahn (2005), and Fry and Lowell (2005), point to substantial differences in marriage rates among the Mexican and Latino communities, and it is well known that, as seen in table 3, immigrants are much more highly urbanized than the third generation. Clearly, these variables are endogenous so interpretation needs to be approached accordingly, but it is interesting to see the relationship in this context. Looking at the coefficients, there is a positive association between being married and having greater years of school in both countries for males, but a negative one for females. The relationship is similar for those who are widowed, separated or divorced for females and US males, but is not different from zero for Canadian males. Perhaps more importantly, there is a difference in the average schooling level between rural and urban areas with those residing in urban areas having higher schooling levels on average, especially in Canada where the gap is over one full year for the males and 0.8 of a year for females. A few individual city indicators are included in the regressions, and these provide some sense of the variety of outcomes across cities. In terms of interpretation, someone living in, for example, New York would receive the schooling gap associated with the city coefficient as well as that for New York. Additional cities could be added to the regression, but this small number is sufficient to illustrate the heterogeneity that exists. These geographic indicators reflect sorting by educational attainment across geographic areas, differential access to education and likely other factors. They should be interpreted solely as conditional correlations in this context. 
Average educational achievement by source region, again controlling only for age using a fourth order polynomial, is presented in table $9 .^{8}$ The sample for each of the regressions is restricted to the group in the column header and the comparison third generation, so all of the coefficients are relative to that group. Note that the categorization is the same as that in table 3 . Also, notice that the immigrant group comprises all immigrants, regardless of age at arrival. Clearly there are substantial differences in average years of schooling across source regions, although there is often a broad similarity in source region coefficient patterns between the United States and Canada as noticed by Borjas (1993). The similarity should not, however, be pushed too far. While it is not universally the case, in many of the comparisons the negative coefficients, e.g. for Mexican immigrants, is not as negative in Canada, and the positive coefficients, e.g. for North Western Europe, is more positive for Canada. The magnitudes tell an interesting story, especially when the US third generation having 0.5 years of additional schooling is taken into account. Within source countries, but interestingly not for Asia, the Canadian system seems to select immigrants with higher levels of education. It seems likely that the Canadian points system is having some effect.

Perhaps the most striking aspect of table 9 is the shift in educational outcomes between the first and second generations. Almost all of the immigrant groups with less education than the third generation type I comparison group have the same or more education in the second generation. The exception to this in both countries is the Mexican subgroup, but even it has the gap reduced substantially (and the actual increase in average educational attainment is quite large for the Mexican group). In contrast, many of the immigrant groups with greater education than the third generation type I group have gaps that increase in the second generation so that they have even more education. The non-UK, English speaking developed country group, and for Canada that from Northwestern Europe, are notable exceptions; for them the gap narrows, although the means stay above the third generation ones. It is worth noting that these groups are the most culturally similar to the third generation. Overall, as seen before, the second generation does very well and accumulates very high levels of schooling on average.

\footnotetext{
${ }^{8}$ For the US regressions a set of survey year indicators were also included in the regressions.
} 


\subsection{Counterfactual Education Predictions}

The substantial differences in educational attainment across source regions for both the first and the second generation, seen in table 9, suggest that the changing country of origin mix of immigrants has implications not only for the first generation, but also for the second since the outcomes between generations are correlated (see e.g., Dicks and Sweetman, 1999; Aydemir, Chen and Corak, 2005). Differences among first generation immigrants will be, although attenuated, transferred to subsequent generations. As mentioned, during the early 1960s both Canada and the US moved away from immigration policies that favored immigrants from Europe and restricted the entry of certain groups. These policy changes resulted in important differences in the country of origin mix as shown in table 3. The differences became more apparent in the last few decades as the share of immigrants from Mexico rose substantially in the US, while for Canada the share of immigrants from Mexico remained at less than one percent.

Given the age restriction of 25-65 in this analysis, the second generation observations in our data are the off-spring of immigrants who arrived three to seven decades ago, and hence they mostly reflect a country of origin mix that is not representative of current migration flows. Therefore, the second generation outcomes we observe today are bound to change in the next few decades as the children of immigrants age and start to reflect country of origin distributions more similar to today's migrants. An interesting question is if, and how much, the outcomes for the second generation will change given these shifts in country of origin. The low level of educational attainment among both the first and second generation Mexican immigrants and their increasing share makes the question especially interesting in the US context.

The complex and not well understood nature of intergenerational educational integration, changing economic incentives and government policies make the answer non-trivial; however, we may still gain some insight if we can make some simplifying assumptions. In order to address this question we first estimate the following regression for a sample of current second generation immigrants:

(2) $S=b_{o}+b_{A}(\text { Age })^{2 n d G e n}+b_{V}(\text { VisMinGroup })^{2 n d G e n}+b_{C}(\text { Re gionofOrigin })^{2 n d G e n}+\varepsilon$ 
where $S$ is years of schooling and we control for a fourth order term in age along with a set of indicator variables for visible minority status and region of origin. The superscripts indicate the sample employed and are relevant in conjunction with equation (3). Given the parameter estimates $b_{A}, b_{V}$ and $b_{C}$ we can predict the schooling level using the visible minority and region of origin characteristics of the current first generation:

(3) $\hat{S}=\hat{b}_{o}+\hat{b}_{A}(\text { Age })^{2 n d G e n}+\hat{b}_{V}(\text { VisMinGroup })^{1 \text { stGen }}+\hat{b}_{C}(\text { Re gionofOrigin })^{1 \text { stGen }}+\varepsilon$

These predicted values provide estimates of schooling level that would be observed among second generation if they had the same visible minority and region of origin characteristics as the immigrants in our sample. This exercise assumes that the underlying factors determining the intergenerational transmission mechanism and visible minority differences of today remain the same in the future. It similarly assumes that any trends in educational attainment affect the second and third generations, recognizing that, depending upon intergenerational marriage, the children of many of the current second generation will become a future third generation.

We carry out the above estimation and prediction by gender for the entire second generation sample and also by second generation subgroups ${ }^{9}$ and report the counterfactual schooling outcomes in Table 10. The top panel shows the average years of schooling for the second and third generation we observe in the data, similar to Table 5. The difference in years of schooling between the second generation and the third generation non-visible minority group is presented in the last four columns. Panel B reports the counterfactual schooling levels for the second generation obtained from the above exercise.

For Canada, the positive differences observed in Panel A between the second generation and the third generation (i.e., second generation has greater years of schooling) increases dramatically in Panel B. Among males, the difference goes up from 0.98 years higher schooling among second generation to 1.66 years. For females the corresponding figures are 0.88 and 1.47. Hence in Canada the second generation further improves its educational advantage relative to the third generation as the children of immigrants from regions such as Asia increase their share

\footnotetext{
${ }^{9}$ We use the characteristics of all immigrants regardless of gender for the prediction. The results are very similar if we use the characteristics of the same gender group (e.g. using only the female first generation immigrant characteristics for predictions of the second generation females).
} 
among the second generation. For the US, on the other hand, the opposite result is observed. The slightly higher schooling level among the second generation males, 26.5 percent of a full year of schooling, almost disappears dropping to 9 percent of a full year, whereas for females 7 percent

of a year of schooling advantage in the first generation disappears and turns into a 16 percent of a year lower schooling. Thus, lower schooling attainment observed among the first generation translates into lower schooling levels among the second generation as the share of source regions such as Mexico increases. One needs to be cautious in interpreting these numbers as they depend on important assumptions, however, these results show that a large inflow of low skilled workers over many decades may substantially alter the second generation's outcomes. These results are reminiscent of inferior second generation immigrant outcomes reported in some European countries (e.g. van Ours and Veenman, 2003) that experienced similar low skill immigrant flows in the past.

\subsection{Basic Earning Regressions}

Turning next to earnings regressions, tables 11a, for males, and 11b, for females, perform the same exercise (with the same format) as tables $8 \mathrm{a}$ and $8 \mathrm{~b}$ did for schooling although there is an extra specification since schooling itself is now a regressor and the sample is, as discussed above, the labor force. These regressions control for age, not potential years of labor market experience as is common. Moreover, they do not control for years-since-migration as does much of the literature. This is because the regressions answer a simple question: how do people of the same age, both controlling and not controlling for other observable characteristics, fare in terms of earnings? If we are interested in poverty and standards of living, then this approach complements the more common use of controls for experience and years since migration; these latter are addressed later. As with education, the findings in the descriptive statistics are reinforced and made stronger once we control for the differences in the age distributions of the different groups.

As seen in columns one and five, immigrants who arrive after age 12 have lower earnings, on average, than members of the third generation of the same age with the gaps being bigger in the US. In contrast, immigrants who arrive young have outcomes that exceed those of 
the native group in Canada, but are below for males, or not different for females, in the US. A broadly similar pattern whereby the second generation does relatively better in Canada is also clear. In the US almost all of the second generation variables have coefficients that are not different from zero, the one exception being those with both parents immigrants who have a marginally positive coefficient. In contrast, every single Canadian second generation coefficient is positive and the point estimates are mostly quite large in magnitude. As seen before, those with two immigrant parents do particularly well Compared to the third, the one-and-a-half and the second generations do much better in Canada.

In columns two and six we add the years of school measure to the regression. Note that the return to schooling coefficient is higher for females than males in both host countries, and higher in the US than in Canada for each sex. Controlling for education serves to reduce, in absolute value, the statistically significant coefficients in the US regressions (shifting them towards zero), but for Canada it makes all the coefficients more negative. In terms of magnitude, adding this variable has little effect on the US second generation coefficients, and serves to explain some of the negative immigrant effects. In Canada, it more appreciably reduces the value of all the immigrant and generational coefficients. Some of the "good” immigrant earnings outcomes are explained by each group’s higher educational attainment in Canada.

In columns three and seven, controls for marital status, ethnicity and urbanization are introduced, but education is removed to isolate the other effects and any partial correlation between schooling and the other controls, and the dependent variable. In the US some of the second generation coefficients become positive and statistically significant, while the coefficient for immigrants becomes slightly more negative. In Canada, as in the previous regression, the generational indicators become more negative suggesting that immigrants and the second generation are, on net, receiving positive premia associated with their set of characteristics. The new regressors' coefficients are unsurprising, but it is worth noting the large marriage (positive for males, negative for females), and urban premiums, given that immigrants are more likely to be married, and they along with the second generation, are more likely to reside in an urban area.

Finally, the specifications in columns four and eight include schooling and the full set of demographic regressors. Overall, for the US the generational coefficients look very much like those in column one, although most of the magnitudes are reduced for immigrants. The second generations' coefficients are neither statistically nor, given the standard errors, even potentially 
substantively different from the third generation, whereas immigrants who arrive after age 12 have negative coefficients, and the younger arriving group less negative and more mixed results.

For the Canadians, the story is more complicated and poses an interesting contrast. Including controls has a substantial influence. For both sexes the generational coefficients are statistically significantly more negative. The second generation coefficients, which are positive and statistically significant in the fifth column, are negative and statistically significant in the eighth. The immigrant coefficients show a similar reduction in their point estimates. This is partly caused by the introduction of the measure of schooling, as discussed, but is equally attributable to the other regressors and does not appear to be driven by the ethnic measures, which induce the opposite effect on their own. (But, note the differences that can be seen in the ethnic coefficients across countries.) It appears that the Canadian immigrant and second generation characteristics, education, marital status and geographic distribution, are such that they more than explain the earnings premia of the one-and-a -half and second generations, and they make the older adult immigrant outcomes look even poorer. This is explored further in the subsequent tables.

Overall, some interesting and substantial differences will be seen between the two countries. In Canada, conditional only on age, the results show immigrants who land at a young age and the second generation to have excellent earnings outcomes. However, this earnings advantage is reduced to zero or becomes negative once one controls for observable characteristics, especially education and urban residence. In the US, unconditionally, immigrants who arrive young have lower, not higher, earnings than the third generation (type I), and the second generation shows no differences. When controls are added there is little change except for a small reduction for the one-and-a-half generation, which becomes somewhat less negative. This is a remarkable difference. In the US the second generation looks a lot like the US third generation, whereas in Canada the second generation has better earnings. This difference is more than explained by observable characteristics, in particular education. This suggests that acculturation/settlement, especially navigating the educational system, occurs quite differently in the two countries to the earnings advantage of Canadian immigrants -- even if they have a low return to those characteristics.

Put another way, the experience of the one-and-a-half and second generation in Canada seems to be one where they collect a premium relative to workers of the same age in the third 
generation. But once additional controls are added the premium not only disappears but becomes negative. Overall, the one-and-a-half and second generations have observed characteristics, especially education, that are associated with high earnings. These characteristics are valued in the market, enough to garner earnings that are higher than those of the third generation, but they are not valued at as high a price as that received by the third generation, so conditional on their observable characteristics the one-and-a-half and second generations receive lower earnings than expected.

\subsection{Earnings Regressions that Allow for Generation-Specific Earnings Effects}

The literature provides evidence of smaller returns to foreign experience and schooling for immigrants than the domestically born population in both the US (e.g., Chiswick and Miller, 1985), and Canada (e.g., Aydemir and Skuterud, 2005). Differences in the return to schooling and potential labor market experience are explored in table 12a, for males, and 12b, for females. Given the large number of interactions that need to be undertaken, we only present results for the major groups - immigrants and second generation. However, in work that is not presented, we find that there are no substantive differences among the sub-groups, so this restriction is not onerous. Unlike table 11, table 12 reports on regressions that control for labor market experience instead of age. As is well known, if all the other regressors are constant, replacing age by potential (Mincer) experience (given that their relationship is an identity) causes the coefficient on schooling to increase, though the increase need not be large if much of the sample is on the flat portion of the age-earnings profile as is the case in this instance. Rather than including a years-since-migration measure, as is common, we split it into two: years of host country schooling, and years of host country potential labor market experience. We believe that differentiating between in-school and post-school years in the host country is potentially important. Also, note that the ethnic variables are not included in these regressions.

In each of tables 12a and 12b base case regressions are presented in column one for the US, and four for Canada. The geographic variables are the focus of table 13, not this table, and are included here simply as controls. Columns two and five in each table introduce experience and years of school interacted with generational status in such a manner that the coefficients on 
the interaction terms measure differences from the base case, which now represents the return to each variable for the third generation. For both sexes, US immigrants have a lower return to the linear component of experience, but a higher coefficient on the quadratic term. Since there is no control for years since migration in these regressions (as is common in research studying economic integration effects following from Chiswick’s (1978) work), the combination of coefficients reflects a lower starting value and the "catching up" that is a focus of interest for immigrants. The Canadian coefficients have one statistically significant positive value for each sex, and one that is not different from zero, but the significant one varies by sex. For the second generation, for males in both countries, there is little difference in the return to experience. However, Canadian females have a higher rate of return, and males a more sharply curving experience profile. The rate of return to schooling is much lower for immigrants than the third generation, especially in Canada. For the second generation, the results are mixed across the countries. In the US there is no statistically significant difference, whereas in Canada the second generation has a lower rate of return than the third generation. (Note that this difference in statistical significance for the males may be an artifact of the greater precision of the Canadian estimates given the larger Canadian sample size, since the two countries’ point estimates are quite similar.) When the interactions are introduced in columns 2 and 5, the generational coefficients increase markedly in value, except for the second generation Canadian males.

The final column for each country in both table 12s splits experience and schooling into that obtained in the source country, and that in the host country. This split is inferred from age at the survey date, age at immigration, and years of schooling assuming that there are no gaps in schooling. Clearly this assumption is only a rough approximation and introduces measurement error that probably biases the coefficient estimates towards zero. ${ }^{10}$ Note that host country experience is similar to what is commonly called an economic integration (economic assimilation) or “years since migration” effect in more conventional specifications in the economics of immigration research literature, but it differs in that it sets all years up to the completion of the highest level of education attained to zero, whereas most use the year of landing for this purpose.

\footnotetext{
${ }^{10}$ Note, however, that this is not white noise measurement error. An underestimate of pre-immigration schooling (and hence experience) implies the converse for the post-immigration measure. Moreover, gaps in education attendance will cause host country education to be underestimated, whereas it is difficult to think of a systematic source of overestimates for source country education.
} 
Clearly, pre-immigration labor market experience is worth a lot less for immigrants than labor market experience is for the third generation, especially in Canada and for US females where the interaction term is larger. In addition to reflecting the value of labor market experience, this can also be interpreted as a substantial negative age-at-immigration effect. As age at immigration increases, so does pre-immigration experience and the earnings gap with the third generation of the same age also grows. In contrast, host country experience has a large and positive coefficient for immigrants, especially in Canada, implying marked wage growth with domestic experience.

The economic return to schooling is everywhere less for immigrants, and the return to pre-immigration schooling is always less than that for post-immigration schooling. The difference in rates of return to schooling is quite substantial, especially in Canada. Note that in this third specification the return to schooling for the second generation becomes more negative in all four sex-country specifications, and the coefficient for males in the US is marginally statistically significant representing a $10 \%$ gap with the third generation. ${ }^{11}$ Neither immigrants nor the second generation appear to have as high a rate of return to education as the third generation, although the gap is much larger for immigrants.

Overall, immigrants appear to have a low rate of return to pre-immigration experience, and a high return to post-immigration experience. Further, immigrants, and to a lesser extent the second generation, appear to receive a lower rate of return to education, even that obtained in the host country. All of these effects are magnified in the Canadian data.

Table 13 extends table 12 by introducing generation-specific location premia. The key story in these regressions is that immigrants, and to a lesser extent the second generation in the US, receive a much smaller urban earnings premium. The effect is especially large for immigrant males in Canada. Moreover, it is complicated by there being city-specific premia that sometimes differ markedly from the overall urban premium and are very heterogeneous. This difference in urban premia is especially important since a very large fraction of immigrants live in cities and, therefore, the aggregate impact is substantial.

\footnotetext{
${ }^{11}$ Recall that although the sample size is quite large overall, the interaction coefficient's statistical significance depends in large part upon the size of the second generation sample, which as seen in table 1 is only a fraction of the total. At least this size of a sample appears to be required to see a $10 \%$ reduction in the rate of return to schooling.
} 


\section{Discussion and Conclusion}

Clearly, there are appreciable differences with respect to both immigrant and second generation characteristics and outcomes between the United States (US) and Canada. Both immigrants and the second generation form a markedly smaller share of the US population following from the lower (combined legal and illegal) US immigration rate. The distribution of source countries is also quite different across the two countries with Mexico, and Central and South America, being much more important source countries for the US.

In contrast to the US, where family reunification is the major source of immigration, Canada has employed a "points system" in the context of a sizeable "economic class" and this has had implications for the educational attainment of immigrants, and it has implications for the second generation. As a result of both the source country distribution and the selection mechanism, immigrants to Canada have, on average, more years of schooling than the third Canadian generation (all references to the third generation refer to the domestic born, non-visible minority population), whereas in the US the third generation has greater years of schooling on average. Interestingly, this effect is particularly important for males, who are more likely to be assessed under the points system than females. In both countries, but more markedly in Canada, the second generation accumulates, on average, more years of schooling than the third generation; however the difference increases for the US when controls for ethnicity and geography are added, but the reverse happens in Canada.

Despite the current second generation having educational outcomes that exceed those of the third generation, these contemporary outcomes may not be a good predictor of educational success for the future second generations since the composition of the immigrant flow has changed in both host countries. We, therefore, perform a counterfactual to predict if future educational outcomes will continue to exceed those of the third generation assuming that the structure of the educational attainment process remains constant, but that the composition of the second generation in the future looks like the current immigrant composition. On this dimension, the two countries continue to diverge. In the future, the second generation in Canada is predicted to have an even larger educational advantage compared to the third generation, but in the US the gap decreases or is eliminated. While the assumptions underlying this counterfactual are unlikely 
to be realized exactly, it does point out that recent immigrants to the US have characteristics associated with lower levels of educational attainment, while the reverse is the case in Canada.

Turning to annual earnings, in regressions controlling for age at the survey date immigrants who arrive younger (age 11 or before - the so-called 1.5 generation) are observed to have an earnings premium relative to the third generation in Canada, but no difference, or a deficit, in the US. Immigrants who arrive older have a substantial earnings deficit relative to the third generation in both countries for both sexes, but it is somewhat larger in the US. The second generation in the US has earnings that are remarkably similar to the third generation there, but in Canada, on average, it has higher earnings, particularly when both parents are immigrants. However, once again the two countries diverge in the manner in which characteristics are treated. The introduction of controls for years of schooling, ethnicity and geography has little (and positive if any) or no effect on the second generation's return in the labor market in the US, but reverses the positive second generation effect in Canada, making it negative. In short, the US second generation population's characteristics, and the rate of return to those characteristics, do not, on net, affect its earnings relative to the third generation. However, the Canadian second generation has characteristics associated with greater earnings potential than the third generation, and while some of that potential is realized in that the former earn more on average, once those characteristics are taken into account the second generation does not earn as much as would the third generation if it had those characteristics. That is, instead of the large premium expected because of their characteristics, the second generation only receives a small one.

Some combination of Canadian selection and settlement policies and practices cause immigrants and the second generation to have superior observed characteristics and these characteristics do have a payoff. That is, the quantity of positive observables is large; Canada's education system seems to retain immigrants and the second generation, especially if both parents are immigrants, and this is of substantial benefit in the labor market although not as much benefit as would be a similar quantity of education for the third generation. In net, the payoff to these characteristics is lower than that for the third generation, sufficiently so that the observed premium conditional only on age for the one-and-a-half and second generations becomes a deficit conditional on a broader range of observable characteristics. No such reversal is observed in the US and the reasons behind this remarkable difference are not fully understood. 
However, part of the reason for the first, and the second, generational earnings differences is that they appear, on average, to have lower rates of return to education, with the magnitude of the difference being larger in Canada. (Future work will see if it is possible to isolate the source of the gaps in rates of return to education to see if it is associated with a particular educational background.) Economic rates of return to potential labor market experience is more complicated, but it appears that the second generation has an equivalent (in the US), or greater (in Canada) return to experience. For immigrants, in both countries the return to pre-immigration experience is smaller than the return for the third generation, and in Canada the net return is actually negative for both sexes. (That is, given the specifications employed, the negative difference between return to labor market experience for immigrants and the second generation is larger than the baseline return to experience shared by both; see table 12a and $b$, column 6.)

Similarly, looking at location premia, neither immigrants nor the second generation appear to receive the earnings premium that the third generation do for living in major urban areas. This is particularly important since in both host countries, immigrants and the second generation are much more likely to reside in an urban area than the third generation. This effect is particularly important in Canada.

Overall, the second generation in both countries has very good educational and labor market outcomes, similar to, and in some cases better than, the third generation, and clearly much better than the first generation. However, the characteristics of current immigrants differ from that of the parents of the current second generation. In the US, current immigrant characteristics, holding the structure of educational attainment and earnings constant, are associated with lower outcomes in the future than is the case for the current second generation, whereas in Canada the reverse can be expected. Looking at annual earnings, the second generation, especially in Canada, does not appear to receive as high a rate of return to its characteristics as does the third generation. Of course, many of those characteristics, such as education and geographic location, are endogenous, and we do not fully understand the process by which they are attained. Most immigrants have, on average, poorer outcomes than the third generation, although the one-and-a-half generation has quite good outcomes in Canada, comparable to the third generation. 


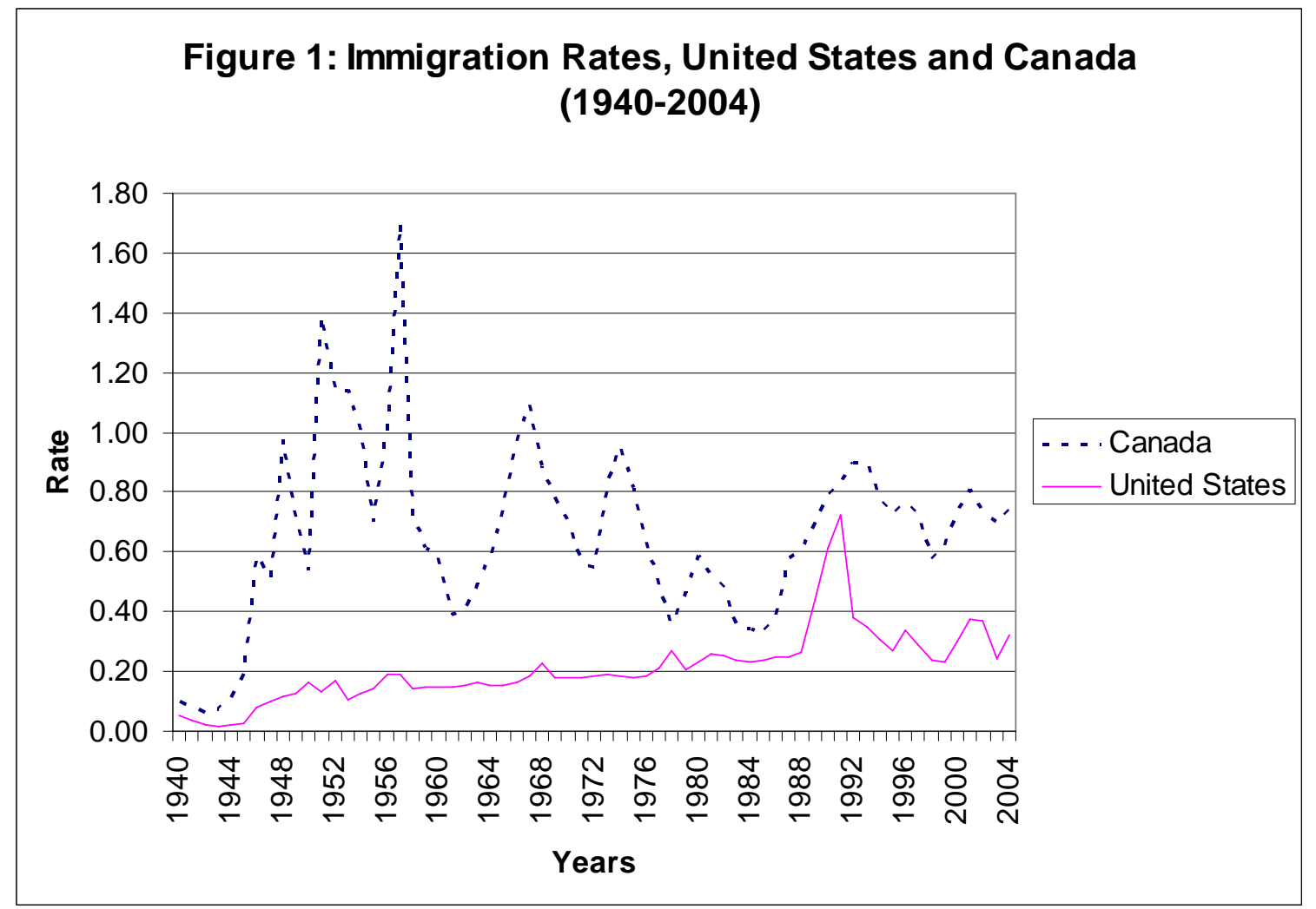

Source: US Citizenship and Immigration Services

(http://uscis.gov/graphics/shared/statistics/yearbook/2004/table1.xls), and Citizenship and Immigration Canada (2005). 


\section{References:}

Aydemir, Abdurrahman, Wen-Hao Chen and Miles Corak. 2005. "Intergenerational Earnings Mobility Among the Children of Canadian Immigrants.” Statistics Canada, Research Paper Series, No. 267.

Aydemir, Abdurrahman and Mikal Skuterud. 2005. "Explaining the Deteriorating Entry Earnings of Canada’s Immigrant Cohorts.” Canadian Journal of Economics, 38(2):641-671.

Baker, Michael, and Dwayne Benjamin. 1994. "The Performance of Immigrants in the Canadian Labor Market.” Journal of Labor Economics, 12(3): 369-405.

Blau, Francine D. and Lawrence M. Kahn. 2005. "Gender And Assimilation among Mexican Americans.” in Mexican Immigration, George Borjas, (Ed.), Chicago: NBER and University of Chicago Press, forthcoming.

Borjas, G.J. 1993. "Immigration Policy, National Origin and Immigrant Skills: A Comparison of Canada and the United States." in Small Differences that Matter: Labor Markets and Income Maintenance in Canada and the United States, edited by D. Card and R. Freeman. Chicago: University of Chicago Press.

Borjas, G.J. 1995. “Assimilation and Changes in Cohort Quality Revisited: What Happened to Immigrant Earnings in the 1980s?” Journal of Labor Economics, 13(2):201-45.

Card, David, John DiNardo and Eugena Estes. 2000. “The More Things Change: Immigrants and the Children of Immigrants in the 1940s, the 1970s, and the 1990s." in Issues in the Economics of Immigration, G.J. Borjas (Ed.), Chicago UP: Chicago, pp. 227-69.

Chiswick, Barry R. 1978. “The Effect of Americanization on the Earnings of Foreign-Born Men.” Journal of Political Economy, 86(5):897-921.

Chiswick, Barry R. 1988. "Differences in Education and Earnings Across Racial and Ethnic Groups: Tastes, Discrimination and Investments in Child Quality.” Quarterly Journal of Economics, 103(3):571-97.

Chiswick, Barry R. and Noyna DebBurman. 2003. "Educational Attainment: analysis by immigrant generation.” Economics of Education Review, 23:361-79.

Chiswick, B.R., and P.W. Miller. 1985. "Immigrant Generation and Income in Australia.” Economic Record, 61(173):540-53.

Citizenship and Immigration Canada. 2005. Facts and Figures: Immigration Overview Permanent and Temporary Residents. Cat. No. Ci1-8/2004E-PDF

Dicks, Gordon, and Arthur Sweetman. 1999. "Education and Ethnicity in Canada: An Intergenerational Perspective.” Journal of Human Resources, 34(4): 668-96. 
Friedberg, R. 1993. "The Labor Market Assimilation of Immigrants in the United States: The Role of Age at Arrival.” mimeo, Brown University.

Fry, Richard, and Lindsay Lowell. 2005. “The Wage Structure of Latino Origin Groups Across Generations.” mimeo, Institute for the Study of International Migration Georgetown University.

Green, Alan G. and David Green. 2004. “The Economic Goals of Canada’s Immigration Policy, Past and Present.” Canadian Journal of Urban Research, 13:102-39.

Kuhn, Peter J. and Arthur Sweetman. 2002. “Aboriginals as Unwilling Immigrants: Contact, Assimilation and Economic Labor Market Outcomes.” Journal of Population Economics, 15(2): 331-55.

Schaafsma, Joseph and Arthur Sweetman. 2001.”Immigrant Earnings: Age at Immigration Matters.” Canadian Journal of Economics, 34(4):1066-99.

Smith, James P. and Barry Edmonston, eds. 1997. The New Americans: Economic, Demographic, and Fiscal Effects of Immigration. Washington: National Academy Press.

van Ours, J. C. and J. Veenman 2003. “The educational attainment of second-generation immigrants in The Netherlands.” Journal of Population Economics, 16(3):739-53. 
Table 1 - Population Shares (\%)

\begin{tabular}{lcccccc} 
& Immigrants & $\begin{array}{c}\text { Second } \\
\text { Generation }\end{array}$ & $\begin{array}{c}\text { Third } \\
\text { Generation I }\end{array}$ & $\begin{array}{c}\text { Third } \\
\text { Generation II }\end{array}$ & Total & N \\
\cline { 2 - 7 } US & 14.6 & 6.0 & 63.7 & 15.7 & 100 & 304165 \\
Canada & 22.6 & 14.3 & 60.1 & 3.0 & 100 & 814054
\end{tabular}

Source: US: 1998-2004 CPS; Canada: 2001 Census. 
Table 2 - Population Shares: Disaggregating Immigrants and 2nd Generation into Subpopulations

\begin{tabular}{|c|c|c|c|c|c|c|}
\hline & \multicolumn{2}{|c|}{ Immigrants } & \multicolumn{3}{|c|}{ Second Generation } \\
\hline & & Imm $>=12$ & Imm<=11 & $\begin{array}{r}\text { Father } \\
\text { only }\end{array}$ & $\begin{array}{r}\text { Mother } \\
\text { only }\end{array}$ & $\begin{array}{r}\text { Both } \\
\text { parents }\end{array}$ \\
\hline \multirow[t]{2}{*}{ US } & $\%$ of population & 12.8 & 1.9 & 1.8 & 1.9 & 2.3 \\
\hline & $\%$ of Generation & 87.1 & 12.9 & 30.0 & 31.1 & 38.9 \\
\hline \multirow[t]{2}{*}{ Canada } & $\%$ of population & 19.1 & 3.4 & 4.4 & 3.1 & 6.8 \\
\hline & $\%$ of Generation & 84.9 & 15.1 & 30.5 & 21.8 & 47.7 \\
\hline
\end{tabular}

Source: US: 1998-2004 CPS; Canada: 2001 Census. 
Table 3 - Geographic Origins of Immigrants and Parents of 2nd Generation

\begin{tabular}{|c|c|c|c|c|c|c|}
\hline & \multirow{3}{*}{$\begin{array}{c}\text { Immigrants } \\
(\%)\end{array}$} & \multicolumn{5}{|c|}{ Second Generation } \\
\hline & & \multicolumn{2}{|c|}{$\begin{array}{c}\text { Parents' } \\
\text { Origins } \\
\end{array}$} & \multicolumn{2}{|c|}{$\begin{array}{c}\text { Probability Both } \\
\text { Parents Immigrants }\end{array}$} & \multirow{2}{*}{$\begin{array}{l}\text { Prob. Both } \\
\text { Immig } \\
\text { Parents Same } \\
\text { Region }\end{array}$} \\
\hline & & $\begin{array}{l}\text { Father } \\
(\%)\end{array}$ & $\begin{array}{l}\text { Mother } \\
(\%)\end{array}$ & $\begin{array}{l}\text { Father } \\
(\%)\end{array}$ & $\begin{array}{l}\text { Mother } \\
(\%)\end{array}$ & \\
\hline \multicolumn{7}{|l|}{ Panel A - US } \\
\hline US & -- & 31.1 & 30.0 & -- & -- & -- \\
\hline Mexico & 27.5 & 14.4 & 13.5 & 64.5 & 69.0 & 97.7 \\
\hline Non-UK, English, Dev. & 2.4 & 5.3 & 6.9 & 29.2 & 26.8 & 76.5 \\
\hline E Europe & 4.7 & 8.0 & 6.2 & 51.1 & 61.1 & 88.1 \\
\hline NW Europe & 5.3 & 12.1 & 15.9 & 46.1 & 36.5 & 82.2 \\
\hline S Europe & 2.6 & 9.9 & 7.3 & 51.4 & 66.4 & 93.1 \\
\hline South America & 6.4 & 1.6 & 1.7 & 66.4 & 67.6 & 79.7 \\
\hline Central America \& Cuba & 9.8 & 3.3 & 3.5 & 57.2 & 56.8 & 84.0 \\
\hline Caribbean & 7.1 & 1.9 & 1.9 & 83.5 & 80.6 & 94.7 \\
\hline Asia & 20.5 & 4.6 & 5.0 & 79.1 & 70.5 & 96.2 \\
\hline Middle East & 2.0 & 1.0 & 0.7 & 56.1 & 79.2 & 86.4 \\
\hline Africa & 2.6 & 0.5 & 0.4 & 48.4 & 55.4 & 72.5 \\
\hline Oceania \& Japan & 6.3 & 3.0 & 4.0 & 63.9 & 50.1 & 90.6 \\
\hline Other & 2.8 & 3.1 & 3.0 & 73.7 & 76.5 & 89.1 \\
\hline \multicolumn{7}{|l|}{ Panel B - Canada } \\
\hline Canada & -- & 21.8 & 30.5 & -- & -- & -- \\
\hline Mexico & 0.7 & 0.3 & 0.3 & 60.3 & 65.9 & 81.6 \\
\hline Non-UK, English, Dev. & 4.5 & 6.6 & 6.6 & 24.4 & 30.5 & 48.5 \\
\hline E Europe & 10.2 & 15.7 & 11.5 & 64.5 & 81.4 & 88.3 \\
\hline NW Europe & 18.9 & 34.8 & 32.5 & 52.4 & 57.9 & 86.5 \\
\hline S Europe & 10.3 & 14.1 & 12.4 & 86.4 & 96.4 & 97.1 \\
\hline South America & 4.1 & 0.5 & 0.5 & 73.1 & 75.9 & 66.5 \\
\hline Central America \& Cuba & 1.7 & 0.2 & 0.2 & 67.3 & 82.3 & 59.6 \\
\hline Caribbean & 5.7 & 1.2 & 1.0 & 76.7 & 86.9 & 84.1 \\
\hline Asia & 29.7 & 3.1 & 2.9 & 86.8 & 91.9 & 93.6 \\
\hline Middle East & 3.2 & 0.6 & 0.5 & 75.2 & 86.7 & 88.6 \\
\hline Africa & 5.5 & 0.7 & 0.5 & 72.4 & 81.8 & 71.2 \\
\hline Oceania \& Japan & 5.6 & 0.6 & 0.6 & 77.8 & 77.8 & 82.6 \\
\hline Other & 0.2 & 0.1 & 0.8 & 25.4 & 59.5 & 54.2 \\
\hline
\end{tabular}

Source: US: 1998-2004 CPS; Canada: 2001 Census. 
Table 4 - Descriptive Statistics (Mean Values) by Generational Status

\begin{tabular}{|c|c|c|c|c|c|c|c|}
\hline \multirow{3}{*}{ Panel A - US } & \multicolumn{2}{|c|}{ Immigrants } & \multicolumn{3}{|c|}{ Second Generation } & \multicolumn{2}{|c|}{ Third Generation } \\
\hline & \multirow[t]{2}{*}{ Imm>=12 } & \multirow[t]{2}{*}{$\operatorname{Imm}<=11$} & \multirow[t]{2}{*}{$\begin{array}{r}\text { Father } \\
\text { only }\end{array}$} & \multirow[t]{2}{*}{$\begin{array}{r}\text { Mother } \\
\text { only }\end{array}$} & \multirow[t]{2}{*}{ Both } & \multirow[t]{2}{*}{$\begin{array}{c}\text { Native born } \\
\text { non-vismin }\end{array}$} & \multirow[t]{2}{*}{ Other } \\
\hline & & & & & & & \\
\hline Age & 41.9 & 36.9 & 46.2 & 42.6 & 40.8 & 43.5 & 41.9 \\
\hline Experience & 24.0 & 17.7 & 26.3 & 22.7 & 21.1 & 23.8 & 23.1 \\
\hline Male & 49.6 & 51.9 & 48.6 & 49.5 & 49.2 & 49.2 & 45.4 \\
\hline Married & 72.9 & 62.6 & 66.9 & 63.7 & 60.1 & 70.2 & 48.2 \\
\hline Widow, Sep, Div & 12.3 & 11.6 & 17.5 & 17.4 & 14.0 & 16.6 & 23.3 \\
\hline Never Married & 14.7 & 25.9 & 15.6 & 18.9 & 25.9 & 13.2 & 28.5 \\
\hline Black & 9.8 & 8.9 & 3.3 & 3.4 & 5.5 & -- & 72.0 \\
\hline Amer. Ind. & 0.8 & 0.8 & 1.2 & 0.9 & 0.7 & -- & 6.9 \\
\hline Asian/P. Islander & 26.7 & 20.4 & 4.4 & 6.6 & 14.7 & -- & 2.8 \\
\hline White & 62.6 & 69.8 & 91.0 & 89.0 & 78.9 & 100.0 & 18.2 \\
\hline Hispanic & 44.5 & 42.2 & 20.1 & 16.6 & 34.4 & -- & 17.2 \\
\hline Born Abroad & -- & -- & 7.3 & 16.8 & 5.9 & -- & 2.4 \\
\hline Urban & 68.4 & 66.2 & 51.2 & 48.5 & 63.6 & 32.5 & 40.0 \\
\hline New York & 16.3 & 15.9 & 11.2 & 9.1 & 17.3 & 5.1 & 6.0 \\
\hline Los Angeles & 17.2 & 17.4 & 8.8 & 7.9 & 12.7 & 3.1 & 5.4 \\
\hline Miami & 4.7 & 5.7 & 1.6 & 1.2 & 3.5 & 0.6 & 1.1 \\
\hline Chicago & 4.2 & 4.2 & 3.6 & 2.8 & 5.1 & 2.5 & 4.2 \\
\hline \multicolumn{8}{|l|}{ Panel B - Canada } \\
\hline Age & 45.6 & 41.4 & 45.2 & 44.3 & 40.2 & 43.4 & 40.6 \\
\hline Experience & 26.1 & 21.1 & 25.4 & 24.4 & 19.8 & 24.2 & 22.7 \\
\hline Male & 47.8 & 50.1 & 48.3 & 50.1 & 50.3 & 49.2 & 47.2 \\
\hline Married & 74.3 & 59.7 & 60.2 & 60.1 & 57.8 & 56.7 & 43.5 \\
\hline Widow, Sep, Div & 13.2 & 13.8 & 16.9 & 16.8 & 12.1 & 17.0 & 18.5 \\
\hline Never Married & 12.5 & 26.5 & 22.9 & 23.0 & 30.1 & 26.3 & 38.0 \\
\hline Black & 7.2 & 4.4 & 0.9 & 0.5 & 2.1 & -- & 6.3 \\
\hline Aboriginal & 0.1 & 0.2 & 2.1 & 1.5 & 0.3 & -- & 83.5 \\
\hline Asian/P. Islander & 41.2 & 14.4 & 1.3 & 1.2 & 6.6 & -- & 5.1 \\
\hline White & 51.5 & 81.0 & 95.7 & 96.8 & 91.1 & 100.0 & 5.1 \\
\hline Hispanic & 7.0 & 4.1 & 0.2 & 0.1 & 1.4 & -- & 1.3 \\
\hline Born Abroad & -- & -- & 0.4 & 1.8 & 0.6 & -- & 4.2 \\
\hline Urban & 90.5 & 80.4 & 65.2 & 64.0 & 78.3 & 56.5 & 39.8 \\
\hline Montreal & 12.0 & 9.1 & 6.3 & 4.7 & 9.2 & 13.2 & 2.3 \\
\hline Toronto & 40.1 & 30.6 & 13.4 & 14.2 & 28.4 & 7.0 & 4.9 \\
\hline Vancouver & 14.3 & 10.5 & 9.2 & 9.1 & 9.6 & 3.8 & 5.4 \\
\hline
\end{tabular}

Source: US: 1998-2004 CPS; Canada: 2001 Census. 
Table 5 - Years of Schooling by Generation

\begin{tabular}{|c|c|c|c|c|c|c|c|}
\hline & \multicolumn{2}{|c|}{ Immigrants } & \multicolumn{3}{|c|}{ Second Generation } & \multicolumn{2}{|c|}{ Third Generation } \\
\hline & Imm>=12 & Imm<=11 & $\begin{array}{r}\text { Father } \\
\text { only }\end{array}$ & $\begin{array}{r}\text { Mother } \\
\text { only }\end{array}$ & Both & $\begin{array}{c}\text { Native Born } \\
\text { non-vismin }\end{array}$ & Other \\
\hline \multicolumn{8}{|l|}{ Males } \\
\hline US & 12.0 & 13.1 & 14.1 & 13.9 & 13.9 & 13.7 & 12.7 \\
\hline Canada & 14.0 & 14.4 & 13.8 & 13.9 & 14.4 & 13.1 & 11.7 \\
\hline \multicolumn{8}{|l|}{ Females } \\
\hline US & 11.8 & 13.2 & 13.8 & 13.8 & 13.6 & 13.7 & 12.9 \\
\hline Canada & 13.2 & 14.1 & 13.8 & 13.9 & 14.5 & 13.2 & 12.0 \\
\hline
\end{tabular}

Source: US: 1998-2004 CPS; Canada: 2001 Census. 
Table 6 - Educational Attainment by Generation (\% at each level)

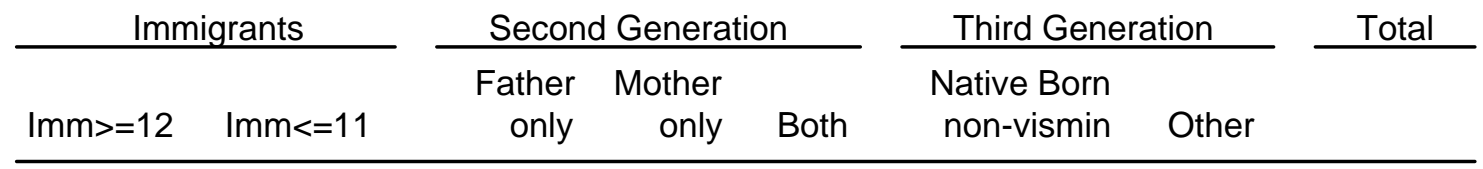

Panel A - US, Male

\begin{tabular}{|c|c|c|c|c|c|c|c|c|}
\hline$<=8$ & 21.4 & 6.5 & 2.6 & 2.3 & 3.3 & 1.9 & 3.7 & 4.9 \\
\hline 9-12, incomplete & 11.7 & 12.9 & 6.2 & 6.3 & 7.5 & 6.7 & 12.9 & 8.4 \\
\hline HS/GED & 23.2 & 26.1 & 25.3 & 26.8 & 25.3 & 32.8 & 38.3 & 31.8 \\
\hline Some Col & 9.6 & 17.3 & 19.5 & 20.3 & 19.1 & 18.1 & 20.9 & 17.5 \\
\hline Assoc & 4.2 & 7.8 & 9.1 & 8.4 & 7.1 & 8.7 & 7.4 & 7.9 \\
\hline Bach & 16.9 & 19.0 & 20.5 & 22.1 & 24.4 & 21.1 & 12.5 & 19.3 \\
\hline MA/MSc & 7.9 & 6.2 & 10.0 & 8.3 & 8.2 & 6.8 & 3.2 & 6.5 \\
\hline Prof Sch & 2.2 & 2.7 & 4.0 & 3.0 & 2.6 & 2.2 & 0.7 & 2.1 \\
\hline $\mathrm{PhD}$ & 2.9 & 1.5 & 2.9 & 2.2 & 2.2 & 1.7 & 0.5 & 1.7 \\
\hline Total & 100 & 100 & 100 & 100 & 100 & 100 & 100 & 100 \\
\hline \multicolumn{9}{|c|}{ Panel B - Canada, Male } \\
\hline$<=8$ & 9.2 & 3.0 & 4.0 & 3.3 & 2.3 & 6.9 & 13.7 & 6.8 \\
\hline 9-12, incomplete & 12.6 & 13.6 & 16.7 & 16.1 & 13.2 & 18.4 & 25.2 & 16.9 \\
\hline HS/GED & 14.4 & 14.9 & 16.7 & 16.0 & 15.1 & 20.2 & 15.4 & 18.1 \\
\hline Some Col & 17.9 & 22.6 & 23.5 & 23.5 & 23.6 & 21.2 & 24.6 & 21.0 \\
\hline Assoc & 16.9 & 19.7 & 18.0 & 18.3 & 20.7 & 16.9 & 13.2 & 17.3 \\
\hline Bach & 15.3 & 16.8 & 13.4 & 14.5 & 16.9 & 10.8 & 5.4 & 12.3 \\
\hline MA/MSc & 7.2 & 4.4 & 4.3 & 4.5 & 3.9 & 2.9 & 1.2 & 3.9 \\
\hline Prof Sch & 4.1 & 4.0 & 2.9 & 3.1 & 3.5 & 2.1 & 0.8 & 2.7 \\
\hline PhD & 2.5 & 0.9 & 0.8 & 0.8 & 0.7 & 0.5 & 0.4 & 0.9 \\
\hline Total & 100 & 100 & 100 & 100 & 100 & 100 & 100 & 100 \\
\hline \multicolumn{9}{|c|}{ Panel C - US, Female } \\
\hline$<=8$ & 21.1 & 7.4 & 2.6 & 1.9 & 4.3 & 1.5 & 2.9 & 4.4 \\
\hline 9-12, incomplete & 10.5 & 9.3 & 7.2 & 5.9 & 7.4 & 5.7 & 13.2 & 7.7 \\
\hline HS/GED & 25.5 & 26.6 & 27.0 & 28.7 & 28.0 & 34.1 & 35.6 & 32.8 \\
\hline Some Col & 9.9 & 16.6 & 20.2 & 20.2 & 18.5 & 18.9 & 21.5 & 18.3 \\
\hline Assoc & 6.1 & 8.1 & 10.1 & 10.2 & 9.1 & 10.4 & 8.9 & 9.5 \\
\hline Bach & 18.9 & 22.4 & 21.9 & 22.2 & 21.2 & 20.3 & 12.7 & 18.9 \\
\hline MA/MSc & 5.4 & 5.8 & 8.9 & 7.8 & 7.9 & 7.3 & 4.2 & 6.6 \\
\hline Prof Sch & 1.3 & 2.6 & 1.2 & 1.8 & 2.6 & 1.0 & 0.7 & 1.1 \\
\hline PhD & 1.1 & 1.3 & 0.8 & 1.4 & 1.1 & 0.8 & 0.4 & 0.8 \\
\hline Total & 100 & 100 & 100 & 100 & 100 & 100 & 100 & 100 \\
\hline \multicolumn{9}{|c|}{ Panel D - Canada, Female } \\
\hline$<=8$ & 12.2 & 3.1 & 2.5 & 2.4 & 1.7 & 5.8 & 11.7 & 6.6 \\
\hline $9-12$, incomplete & 13.8 & 12.1 & 16.7 & 15.4 & 11.3 & 16.7 & 23.1 & 15.8 \\
\hline $\mathrm{HS} / \mathrm{GED}$ & 15.9 & 17.8 & 16.5 & 17.0 & 15.6 & 20.6 & 12.9 & 18.7 \\
\hline Some Col & 14.6 & 17.4 & 17.3 & 16.4 & 16.9 & 15.9 & 22.1 & 16.1 \\
\hline Assoc & 20.6 & 24.9 & 26.2 & 26.7 & 26.8 & 24.3 & 20.9 & 23.8 \\
\hline Bach & 14.1 & 16.6 & 14.5 & 14.9 & 19.2 & 11.8 & 7.1 & 12.9 \\
\hline MA/MSc & 4.7 & 4.0 & 3.4 & 3.7 & 3.8 & 2.5 & 1.3 & 3.1 \\
\hline Prof Sch & 3.2 & 3.6 & 2.7 & 3.1 & 4.2 & 2.1 & 0.9 & 2.5 \\
\hline PhD & 0.8 & 0.5 & 0.4 & 0.4 & 0.4 & 0.2 & 0.1 & 0.4 \\
\hline Total & 100 & 100 & 100 & 100 & 100 & 100 & 100 & 100 \\
\hline
\end{tabular}

Source: US: 1998-2004 CPS; Canada: 2001 Census. 
Table 7 - Labour Force Attachment by Generation

\begin{tabular}{|c|c|c|c|c|c|c|}
\hline \multicolumn{2}{|c|}{ Immigrants } & \multicolumn{3}{|c|}{ Second Generation } & \multicolumn{2}{|c|}{ Third Generation } \\
\hline $\mid \mathrm{mm}>=12$ & Imm $<=11$ & $\begin{array}{r}\text { Father } \\
\text { only }\end{array}$ & $\begin{array}{r}\text { Mother } \\
\text { only }\end{array}$ & Both & $\begin{array}{l}\text { Native Born } \\
\text { non-vismin }\end{array}$ & Other \\
\hline
\end{tabular}

Panel A - Males

US

Employed (\%)

Unemployed (\%)

Out of LF (\%)

Total (\%)

In Schl FT (\%)

Weeks Work in $\mathrm{Yr}$

Annual Earnings (\$)

$\begin{array}{rr}85.4 & 86.2 \\ 4.6 & 4.4 \\ 10.0 & 9.5 \\ 100 & 100 \\ 2.3 & 3.3 \\ 43.7 & 44.6 \\ 32282 & 36978\end{array}$

81.4

$84.9 \quad 82.5$

3.8

$\begin{array}{rrr}3.4 & 4.1 & 3.8 \\ 15.1 & 10.9 & 13.7\end{array}$

100

$100 \quad 100$

2.9

$\begin{array}{rrr}1.7 & 1.6 & 2.9 \\ 42.2 & 44.2 & 43.4\end{array}$

$43650 \quad 44522 \quad 40840$

84.6

74.6

Canada

Employed (\%)

Unemployed (\%)

Out of LF (\%)

Total (\%)

In Schl FT (\%)

Weeks Work in $\mathrm{Yr}$

$\begin{array}{rr}78.0 & 85.9 \\ 5.3 & 4.3 \\ 16.7 & 9.7 \\ 100 & 100 \\ 3.6 & 3.7 \\ 38.4 & 43.3 \\ 33167 & 43884\end{array}$

$80.4 \quad 82.4$

84.7

3.7

$\begin{array}{rrr}4.4 & 4.1 & 3.7 \\ 15.2 & 13.5 & 11.5\end{array}$

$100 \quad 100 \quad 100$

Annual Earnings (\$)

2.6
40.2
40100

2.8

3.5

42.5

41.4

42313

3.3

6.2

12.0

19.1

Panel B - Females

US

Employed (\%)

Unemployed (\%)

Out of LF (\%)

Total (\%)

In Schl FT (\%)

Weeks Work in $\mathrm{Yr}$

Annual Earnings (\$)

$\begin{array}{rr}58.2 & 71.4 \\ 4.3 & 3.1 \\ 37.5 & 25.5 \\ 100 & 100 \\ 2.8 & 2.6 \\ 29.3 & 35.9 \\ 14580 & 22255\end{array}$

69.9

74.6

69.9

2.7

3.0

3.3

$\begin{array}{lll}27.4 & 22.4 & 26.8\end{array}$

$100 \quad 100$

$1.1 \quad 1.4$

$44.2 \quad 39.2$

$42074 \quad 27509$

\section{Canada}

Employed (\%)

Unemployed (\%)

Out of LF (\%)

Total (\%)

In Schl FT (\%)

Weeks Work in $\mathrm{Yr}$

Annual Earnings (\$)

$\begin{array}{rr}61.4 & 77.0 \\ 5.2 & 3.4 \\ 33.4 & 19.5 \\ 100 & 100 \\ 4.0 & 3.4 \\ 29.6 & 37.8 \\ 17606 & 26914\end{array}$

$\begin{array}{rrr}69.3 & 71.0 & 74.4 \\ 3.2 & 3.9 & 3.4 \\ 27.5 & 25.1 & 22.2 \\ 100 & 100 & 100 \\ 2.9 & 2.8 & 3.7 \\ 34.0 & 34.9 & 36.7 \\ 22386 & 23457 & 25853\end{array}$

$69.8 \quad 56.8$

$4.1 \quad 9.0$

$26.1 \quad 34.1$

$100 \quad 100$

Source: US: 1998-2004 CPS; Canada: 2001 Census. 
Table 8A - Educational Attainment by Generation, Males

\begin{tabular}{|c|c|c|c|c|c|c|}
\hline & \multicolumn{3}{|c|}{ US } & \multicolumn{3}{|c|}{ Canada } \\
\hline & 1 & 2 & 3 & 4 & 5 & 6 \\
\hline $\mathrm{imm}<=11$ & $\begin{array}{l}-0.552^{\star \star \star} \\
{[0.082]}\end{array}$ & $\begin{array}{l}0.865^{\star \star \star} \\
{[0.083]}\end{array}$ & $\begin{array}{l}0.550 * \star \star \\
{[0.084]}\end{array}$ & $\begin{array}{l}1.081 * * * \\
{[0.033]}\end{array}$ & $\begin{array}{l}1.055^{\star \star \star} \\
{[0.034]}\end{array}$ & $\begin{array}{l}0.570 * * \star \\
{[0.034]}\end{array}$ \\
\hline $\mathrm{imm}>=12$ & $\begin{array}{l}-1.753^{\star \star \star} \\
{[0.045]}\end{array}$ & $\begin{array}{l}-0.228^{\star \star \star} \\
{[0.056]}\end{array}$ & $\begin{array}{l}-0.597^{\star \star \star} \\
{[0.058]}\end{array}$ & $\begin{array}{l}1.009 * \star \star \\
{[0.020]}\end{array}$ & $\begin{array}{l}0.897^{\star \star *} \\
{[0.025]}\end{array}$ & $\begin{array}{l}0.272^{\star \star *} \\
{[0.026]}\end{array}$ \\
\hline Gen2-Mom & $\begin{array}{l}0.251^{\star * \star} \\
{[0.066]}\end{array}$ & $\begin{array}{l}0.788^{\star \star \star} \\
{[0.065]}\end{array}$ & $\begin{array}{l}0.644^{* \star *} \\
{[0.064]}\end{array}$ & $\begin{array}{l}0.857^{\star * *} \\
{[0.034]}\end{array}$ & $\begin{array}{l}0.877^{\star \star *} \\
{[0.034]}\end{array}$ & $\begin{array}{l}0.576^{\star \star \star} \\
{[0.034]}\end{array}$ \\
\hline Gen2-Dad & $\begin{array}{l}0.407^{\star \star \star} \\
{[0.072]}\end{array}$ & $\begin{array}{l}1.137^{\star \star *} \\
{[0.070]}\end{array}$ & $\begin{array}{l}0.961^{* \star *} \\
{[0.070]}\end{array}$ & $\begin{array}{l}0.799 * * \star \\
{[0.029]}\end{array}$ & $\begin{array}{l}0.827^{\star * \star} \\
{[0.029]}\end{array}$ & $\begin{array}{l}0.510^{\star \star \star} \\
{[0.029]}\end{array}$ \\
\hline Gen2-Both & $\begin{array}{l}0.239 * \star \star \\
{[0.067]}\end{array}$ & $\begin{array}{l}1.327^{\star \star \star} \\
{[0.069]}\end{array}$ & $\begin{array}{l}1.047^{\star \star \star *} \\
{[0.069]}\end{array}$ & $\begin{array}{l}1.145^{\star \star \star} \\
{[0.023]}\end{array}$ & $\begin{array}{l}1.135^{\star \star \star} \\
{[0.023]}\end{array}$ & $\begin{array}{l}0.668^{\star \star \star} \\
{[0.024]}\end{array}$ \\
\hline Black & & $\begin{array}{l}-0.398^{\star \star \star} \\
{[0.102]}\end{array}$ & $\begin{array}{l}-0.508^{\star \star \star} \\
{[0.103]}\end{array}$ & & $\begin{array}{l}0.199^{* \star *} \\
{[0.065]}\end{array}$ & $\begin{array}{c}0.160^{\star *} \\
{[0.065]}\end{array}$ \\
\hline Amer. Ind. / Aboriginal & & $\begin{array}{r}-0.431 \\
{[0.273]}\end{array}$ & $\begin{array}{c}-0.374 \\
{[0.271]}\end{array}$ & & $\begin{array}{l}-1.798^{\star \star \star} \\
{[0.131]}\end{array}$ & $\begin{array}{l}-1.572^{\star \star \star} \\
{[0.130]}\end{array}$ \\
\hline Asian/P. Islander & & $\begin{array}{l}0.910^{\star * \star} \\
{[0.072]}\end{array}$ & $\begin{array}{l}0.902^{\star * *} \\
{[0.074]}\end{array}$ & & $\begin{array}{l}0.358^{\star \star \star} \\
{[0.034]}\end{array}$ & $\begin{array}{l}0.124^{\star \star \star} \\
{[0.035]}\end{array}$ \\
\hline Hispanic & & $\begin{array}{l}-3.643^{\star \star \star} \\
{[0.064]}\end{array}$ & $\begin{array}{l}-3.651^{\star \star \star} \\
{[0.065]}\end{array}$ & & $\begin{array}{l}-0.696^{\star \star \star} \\
{[0.069]}\end{array}$ & $\begin{array}{l}-0.735^{\star \star \star} \\
{[0.069]}\end{array}$ \\
\hline Married & & & $\begin{array}{l}0.349^{* \star \star} \\
{[0.030]}\end{array}$ & & & $\begin{array}{l}0.490^{\star \star \star} \\
{[0.017]}\end{array}$ \\
\hline Widow, Divorced or Sep. & & & $\begin{array}{l}-0.352^{\star \star \star} \\
{[0.039]}\end{array}$ & & & $\begin{array}{c}-0.034 \\
{[0.024]}\end{array}$ \\
\hline Urban & & & $\begin{array}{l}0.651^{\star \star \star} \\
{[0.033]}\end{array}$ & & & $\begin{array}{l}1.145^{\star \star \star} \\
{[0.016]}\end{array}$ \\
\hline NY/ Montreal & & & $\begin{array}{l}0.186^{\star * *} \\
{[0.066]}\end{array}$ & & & $\begin{array}{l}0.118^{\star * *} \\
{[0.030]}\end{array}$ \\
\hline LA / Toronto & & & $\begin{array}{l}-0.317^{\star \star \star} \\
{[0.073]}\end{array}$ & & & $\begin{array}{l}0.161^{\star \star \star} \\
{[0.024]}\end{array}$ \\
\hline Miami / Vancouver & & & $\begin{array}{l}0.639 * * * \\
{[0.115]}\end{array}$ & & & $\begin{array}{l}-0.202^{\star \star *} \\
{[0.038]}\end{array}$ \\
\hline Chicago & & & $\begin{array}{c}0.099 \\
{[0.085]}\end{array}$ & & & $\begin{array}{l}--- \\
---\end{array}$ \\
\hline State/Prov Indicators & No & No & Yes & No & No & Yes \\
\hline Observations & 108521 & 108521 & 108521 & 362799 & 362799 & 362799 \\
\hline $\mathrm{R}^{2}$ & 0.0493 & 0.1434 & 0.1691 & 0.051 & 0.0524 & 0.0837 \\
\hline
\end{tabular}

Source: US: 1998-2004 CPS; Canada: 2001 Census.

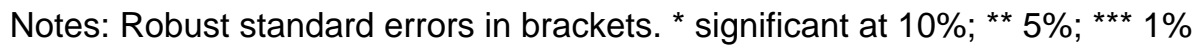
Each regression also includes a fourth order polynomial in age. Regressions for the US also include six year indicators reflecting the underlying merged set of CPS samples. 
Table 8B - Educational Attainment by Generation, Females

\begin{tabular}{|c|c|c|c|c|c|c|}
\hline & \multicolumn{3}{|c|}{ US } & \multicolumn{3}{|c|}{ Canada } \\
\hline & 1 & 2 & 3 & 4 & 5 & 6 \\
\hline \multirow[t]{2}{*}{$\mathrm{imm}<=11$} & $-0.556^{\star \star \star}$ & $0.678^{\star \star \star}$ & $0.369 * \star \star$ & $0.668^{\star \star \star}$ & $0.688^{\star \star *}$ & $0.307^{\star \star *}$ \\
\hline & {$[0.081]$} & {$[0.081]$} & {$[0.082]$} & {$[0.031]$} & {$[0.032]$} & [0.032] \\
\hline \multirow[t]{2}{*}{ imm>=12 } & $-1.914 * \star \star$ & $-0.611^{\star * *}$ & $-0.923^{\star \star \star}$ & $0.103^{\star \star \star}$ & $0.152^{\star \star \star}$ & $-0.260 * \star \star$ \\
\hline & {$[0.041]$} & {$[0.050]$} & {$[0.051]$} & [0.019] & {$[0.024]$} & {$[0.025]$} \\
\hline \multirow[t]{2}{*}{ Gen2-Mom } & $0.155^{\star \star \star}$ & $0.692^{\star \star \star}$ & $0.571^{\star \star \star}$ & $0.717^{\star \star \star}$ & $0.735^{\star \star \star}$ & $0.484^{\star * *}$ \\
\hline & [0.059] & {$[0.060]$} & {$[0.059]$} & {$[0.030]$} & {$[0.030]$} & [0.030] \\
\hline \multirow[t]{2}{*}{ Gen2-Dad } & $0.213^{\star \star \star}$ & $0.869 * * \star$ & $0.704^{\star \star \star}$ & $0.721^{\star \star \star}$ & $0.747^{\star \star \star}$ & $0.488^{* \star *}$ \\
\hline & [0.061] & [0.059] & [0.059] & [0.025] & [0.025] & [0.025] \\
\hline \multirow[t]{2}{*}{ Gen2-Both } & -0.031 & $1.052^{\star \star \star}$ & $0.765^{\star \star \star}$ & $0.985^{\star \star \star}$ & $0.994^{\star \star \star}$ & $0.613^{* * *}$ \\
\hline & [0.063] & [0.063] & [0.064] & [0.021] & [0.021] & [0.022] \\
\hline \multirow[t]{2}{*}{ Black } & & $-0.287^{\star \star \star}$ & $-0.529 * * \star$ & & $0.177^{\star \star \star}$ & 0.071 \\
\hline & & {$[0.089]$} & {$[0.092]$} & & {$[0.063]$} & {$[0.063]$} \\
\hline \multirow[t]{2}{*}{ Amer. Ind. / Aboriginal } & & -0.343 & -0.285 & & $-1.194^{\star \star \star}$ & $-1.035^{\star * *}$ \\
\hline & & {$[0.273]$} & {$[0.273]$} & & [0.109] & {$[0.110]$} \\
\hline \multirow[t]{2}{*}{ Asian/P. Islander } & & $0.435^{\star \star *}$ & $0.468^{* \star *}$ & & $-0.076^{\star \star}$ & $-0.260 * \star \star$ \\
\hline & & {$[0.069]$} & {$[0.071]$} & & {$[0.032]$} & [0.033] \\
\hline \multirow[t]{2}{*}{ Hispanic } & & $-3.262^{\star \star \star}$ & $-3.208^{\star \star \star}$ & & $-0.386^{\star \star \star}$ & $-0.407^{* * *}$ \\
\hline & & {$[0.060]$} & {$[0.061]$} & & {$[0.065]$} & {$[0.065]$} \\
\hline \multirow[t]{2}{*}{ Married } & & & $-0.135^{\star \star \star}$ & & & $-0.329 * * *$ \\
\hline & & & {$[0.033]$} & & & [0.018] \\
\hline \multirow[t]{2}{*}{ Widow, Divorced or Sep. } & & & $-0.613^{\star \star \star}$ & & & $-0.614^{\star \star \star}$ \\
\hline & & & {$[0.038]$} & & & {$[0.022]$} \\
\hline \multirow[t]{2}{*}{ Urban } & & & $0.525^{\star \star \star}$ & & & $0.801^{* * *}$ \\
\hline & & & {$[0.030]$} & & & [0.014] \\
\hline \multirow[t]{2}{*}{ NY/ Montreal } & & & 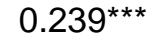 & & & $0.092^{\star \star \star}$ \\
\hline & & & {$[0.059]$} & & & {$[0.028]$} \\
\hline \multirow{2}{*}{ LA / Toronto } & & & $-0.335^{\star \star \star}$ & & & $0.117^{\star \star \star}$ \\
\hline & & & {$[0.069]$} & & & [0.022] \\
\hline \multirow{2}{*}{ Miami / Vancouver } & & & $0.687^{\star \star \star}$ & & & -0.041 \\
\hline & & & {$[0.108]$} & & & [0.034] \\
\hline \multirow{2}{*}{ Chicago } & & & $0.245^{\star \star \star}$ & & & --- \\
\hline & & & {$[0.080]$} & & & --- \\
\hline State/Prov Indicators & No & No & Yes & No & No & Yes \\
\hline Observations & 114697 & 114697 & 114697 & 377934 & 377934 & 377934 \\
\hline $\mathrm{R}^{2}$ & 0.0694 & 0.1459 & 0.1685 & 0.0859 & 0.0863 & 0.1072 \\
\hline
\end{tabular}

Source: US: 1998-2004 CPS; Canada: 2001 Census.

Notes: Robust standard errors in brackets. * significant at 10\%; ** $5 \%$; *** $1 \%$

Each regression also includes a fourth order polynomial in age. Regressions for the US also include six year indicators reflecting the underlying merged set of CPS samples. 
Table 9 - Educational Attainment by Region of Origin

\begin{tabular}{|c|c|c|c|c|c|c|c|c|}
\hline & \multicolumn{4}{|c|}{ US } & \multicolumn{4}{|c|}{ Canada } \\
\hline & \multirow[b]{2}{*}{ Immigrants } & \multicolumn{3}{|c|}{ Second Generation } & \multirow[b]{2}{*}{ Immigrants } & \multicolumn{3}{|c|}{ Second Generation } \\
\hline & & Father only & Mother only & $\begin{array}{c}\text { Two Parents } \\
\text { Same Rgn }\end{array}$ & & Father only & Mother only & $\begin{array}{c}\text { Two Parents } \\
\text { Same Rgn }\end{array}$ \\
\hline \multicolumn{9}{|l|}{ Panel A - Male } \\
\hline \multirow[t]{2}{*}{ Mexico } & $-4.925^{\star \star \star}$ & $-1.538^{\star \star \star}$ & $-1.857^{\star * \star}$ & $-1.544^{\star \star \star}$ & $-2.146^{\star \star \star}$ & $-1.327^{\star *}$ & -0.147 & $-3.384^{\star \star *}$ \\
\hline & {$[0.069]$} & {$[0.197]$} & {$[0.218]$} & {$[0.132]$} & {$[0.246]$} & {$[0.558]$} & {$[0.557]$} & {$[0.410]$} \\
\hline \multirow[t]{2}{*}{ Non-UK, English, Dev. } & $0.856^{\star \star \star}$ & $0.546^{\star \star \star}$ & $0.627^{* \star *}$ & 0.263 & $2.534^{\star \star \star}$ & $0.642^{\star * \star}$ & $0.777^{* \star *}$ & $0.466^{\star \star \star}$ \\
\hline & {$[0.156]$} & {$[0.159]$} & [0.132] & {$[0.242]$} & {$[0.069]$} & {$[0.075]$} & {$[0.076]$} & {$[0.176]$} \\
\hline \multirow[t]{2}{*}{ Eastern Europe } & $0.558^{* \star *}$ & $1.500^{* * *}$ & $1.135^{\star * \star}$ & $1.109 * \star \star$ & $1.770^{\star * \star}$ & $0.925^{\star * \star}$ & $1.291^{\star * \star}$ & $1.697^{\star \star \star}$ \\
\hline & {$[0.125]$} & {$[0.165]$} & {$[0.213]$} & {$[0.208]$} & {$[0.042]$} & {$[0.067]$} & {$[0.106]$} & {$[0.056]$} \\
\hline \multirow[t]{2}{*}{ North Western Europe } & $1.266^{\star \star \star}$ & $1.006^{\star \star \star}$ & $0.502^{\star * \star}$ & $1.158^{\star \star \star}$ & $1.833^{\star * *}$ & $0.783^{\star * \star}$ & $0.765^{\star \star \star}$ & $0.857^{* \star *}$ \\
\hline & {$[0.115]$} & [0.133] & [0.108] & [0.138] & {$[0.030]$} & [0.038] & {$[0.042]$} & {$[0.037]$} \\
\hline \multirow[t]{2}{*}{ South Europe } & $-1.345^{\star \star \star}$ & $0.418 * \star \star$ & $0.363^{*}$ & $0.345^{\star \star}$ & $-2.327^{\star \star \star}$ & $0.742^{\star \star \star}$ & $1.018^{\star \star \star}$ & $0.847^{* * *}$ \\
\hline & {$[0.192]$} & [0.159] & {$[0.210]$} & {$[0.144]$} & {$[0.052]$} & [0.108] & [0.183] & {$[0.041]$} \\
\hline \multirow[t]{2}{*}{ South America } & $-0.621^{\star \star \star}$ & 0.51 & $0.975^{\star \star}$ & 0.470 & $0.875^{\star \star \star}$ & $1.203^{\star \star \star}$ & $0.736^{\star \star}$ & $0.529 * \star$ \\
\hline & {$[0.109]$} & {$[0.463]$} & {$[0.421]$} & {$[0.364]$} & {$[0.074]$} & {$[0.446]$} & {$[0.364]$} & {$[0.251]$} \\
\hline \multirow[t]{2}{*}{ Central America \& Cuba } & $-2.929 * \star \star$ & -0.407 & 0.164 & $0.493^{\star *}$ & -0.124 & $1.464^{\star \star \star}$ & $2.198 * \star \star$ & $1.324^{* * *}$ \\
\hline & {$[0.112]$} & {$[0.315]$} & {$[0.246]$} & {$[0.243]$} & [0.122] & {$[0.461]$} & {$[0.606]$} & {$[0.324]$} \\
\hline \multirow[t]{2}{*}{ Caribbean } & $-1.513^{\star \star \star}$ & 0.413 & $1.072^{\star \star}$ & 0.102 & $0.507^{\star \star \star}$ & $1.046^{\star \star \star}$ & $1.785^{\star \star \star}$ & $1.251^{\star \star \star}$ \\
\hline & [0.118] & [0.582] & [0.515] & {$[0.445]$} & [0.064] & [0.291] & [0.396] & [0.186] \\
\hline \multirow[t]{2}{*}{ Asia } & $0.983^{\star * \star}$ & $1.781^{\star \star \star}$ & $0.549 *$ & $1.853^{\star * *}$ & $1.111^{\star \star \star}$ & $1.564^{\star \star \star}$ & $2.028 * \star \star *$ & $2.481^{\star \star \star}$ \\
\hline & {$[0.070]$} & {$[0.366]$} & {$[0.287]$} & [0.208] & {$[0.034]$} & {$[0.216]$} & {$[0.320]$} & [0.102] \\
\hline \multirow[t]{2}{*}{ Middle East } & 0.033 & $1.469^{\star *}$ & 0.505 & 0.330 & $0.994^{\star \star \star}$ & $1.578^{\star \star \star}$ & $2.255^{\star \star \star}$ & $1.628^{\star * \star}$ \\
\hline & {$[0.205]$} & {$[0.637]$} & [0.809] & [0.445] & {$[0.096]$} & [0.388] & {$[0.438]$} & {$[0.243]$} \\
\hline \multirow[t]{2}{*}{ Africa } & $1.157^{\star \star \star}$ & 0.640 & $1.687^{\star * \star}$ & 1.225 & $2.673^{\star \star \star}$ & $1.702^{\star \star \star}$ & $1.666^{\star \star \star}$ & $2.492^{\star \star \star}$ \\
\hline & {$[0.144]$} & {$[0.554]$} & {$[0.524]$} & {$[0.972]$} & [0.063] & [0.335] & {$[0.572]$} & [0.322] \\
\hline \multirow[t]{2}{*}{ Oceania \& Japan } & $0.983^{\star \star \star}$ & 0.342 & $0.402^{\star \star}$ & $1.309 * * \star$ & $1.607^{\star \star \star}$ & $2.445^{\star \star \star}$ & $1.916^{\star \star \star}$ & $1.722^{\star \star \star}$ \\
\hline & [0.111] & [0.343] & [0.188] & {$[0.220]$} & {$[0.062]$} & {$[0.459]$} & [0.344] & [0.258] \\
\hline \multirow[t]{2}{*}{ Other } & $-1.114^{\star \star \star}$ & $0.789 *$ & 0.443 & $-0.983^{\star \star \star}$ & $-1.094^{\star * \star}$ & $-2.303^{\star \star \star}$ & $-2.317^{\star}$ & $0.654 * \star \star$ \\
\hline & {$[0.201]$} & {$[0.457]$} & [0.351] & [0.331] & [0.012] & [0.854] & [1.260] & [0.012] \\
\hline Observations & 101264 & 88070 & 88217 & 88159 & 308958 & 244279 & 239959 & 250551 \\
\hline $\mathrm{R}^{2}$ & 0.1685 & 0.0119 & 0.0111 & 0.0141 & 0.0812 & 0.0435 & 0.0435 & 0.0534 \\
\hline
\end{tabular}


Panel B - Female

\begin{tabular}{|c|c|c|c|c|c|c|c|c|}
\hline Mexico & $\begin{array}{l}-5.105^{\star \star \star} \\
{[0.072]}\end{array}$ & $\begin{array}{l}-1.532^{\star \star *} \\
{[0.176]}\end{array}$ & $\begin{array}{l}-1.466^{\star \star \star} \\
{[0.200]}\end{array}$ & $\begin{array}{l}-1.867^{\star \star \star} \\
{[0.134]}\end{array}$ & $\begin{array}{l}-1.446^{\star \star \star} \\
{[0.225]}\end{array}$ & $\begin{array}{c}-0.758^{\star} \\
{[0.417]}\end{array}$ & $\begin{array}{l}-1.469 * \star \star \\
{[0.410]}\end{array}$ & $\begin{array}{l}-2.404^{\star \star \star} \\
{[0.328]}\end{array}$ \\
\hline \multirow[t]{2}{*}{ Non-UK, English, Dev. } & $0.714^{* \star *}$ & $0.594^{\star \star \star}$ & $0.431^{* \star *}$ & -0.142 & $2.028^{* \star *}$ & $0.519^{* * *}$ & $0.700^{\star * *}$ & $0.806^{\star * \star}$ \\
\hline & [0.128] & [0.159] & {$[0.140]$} & [0.196] & [0.053] & {$[0.062]$} & {$[0.066]$} & {$[0.171]$} \\
\hline \multirow[t]{2}{*}{ Eastern Europe } & $0.664^{\star \star \star}$ & $1.037^{\star \star \star}$ & $0.851^{\star \star *}$ & $1.031^{\star \star *}$ & $1.286^{\star \star \star}$ & $0.906^{\star \star *}$ & $0.996^{\star \star \star}$ & $1.423^{\star \star *}$ \\
\hline & [0.105] & {$[0.137]$} & [0.195] & [0.156] & {$[0.040]$} & [0.054] & [0.094] & {$[0.048]$} \\
\hline \multirow[t]{2}{*}{ North Western Europe } & $0.530^{* * *}$ & $0.602^{\star \star \star}$ & $0.348^{* \star *}$ & $0.955^{\star \star \star}$ & $1.336^{\star * \star}$ & $0.633^{\star * *}$ & $0.636^{\star \star \star}$ & $0.657^{* * *}$ \\
\hline & [0.091] & [0.104] & [0.088] & [0.128] & {$[0.026]$} & [0.033] & {$[0.037]$} & [0.033] \\
\hline \multirow[t]{2}{*}{ South Europe } & $-2.006^{\star \star \star}$ & 0.061 & $0.295^{\star}$ & $0.324^{\star *}$ & $-3.301^{* \star \star}$ & $0.838^{* \star *}$ & $0.843^{\star \star \star}$ & $0.783^{\star \star \star *}$ \\
\hline & {$[0.201]$} & {$[0.126]$} & {$[0.176]$} & [0.136] & {$[0.050]$} & [0.099] & {$[0.250]$} & [0.039] \\
\hline \multirow[t]{2}{*}{ South America } & $-0.709 * \star \star$ & $1.126^{\star \star \star}$ & $0.813^{\star *}$ & 0.671 & $0.157^{\star \star}$ & $1.336^{\star \star \star}$ & $1.084^{\star \star \star}$ & $0.973^{\star \star *}$ \\
\hline & [0.101] & [0.404] & [0.327] & [0.415] & [0.068] & [0.347] & {$[0.400]$} & [0.313] \\
\hline \multirow[t]{2}{*}{ Central America \& Cuba } & $-2.881^{\star \star \star}$ & 0.138 & -0.384 & -0.033 & $-0.615^{\star \star \star}$ & 0.532 & $1.533^{*}$ & $1.365^{\star \star \star}$ \\
\hline & [0.112] & [0.223] & {$[0.236]$} & [0.296] & [0.133] & [0.481] & {$[0.834]$} & [0.359] \\
\hline \multirow[t]{2}{*}{ Caribbean } & $-1.721^{\star \star \star}$ & 0.495 & $1.043^{\star \star}$ & 0.413 & $0.219 * \star \star$ & $1.414^{\star \star \star}$ & $1.050^{\star \star \star *}$ & $1.151^{\star \star \star}$ \\
\hline & [0.101] & {$[0.536]$} & [0.494] & {$[0.286]$} & [0.054] & [0.289] & [0.385] & {$[0.170]$} \\
\hline \multirow[t]{2}{*}{ Asia } & $-0.201^{\star \star \star}$ & $1.632^{\star \star \star}$ & $0.655^{\star \star}$ & $1.088^{\star \star \star}$ & $-0.325^{\star \star \star}$ & $1.913^{\star \star \star}$ & $2.066^{\star \star \star}$ & $1.959^{\star \star \star}$ \\
\hline & [0.075] & [0.300] & {$[0.259]$} & [0.234] & [0.032] & [0.261] & [0.347] & {$[0.092]$} \\
\hline \multirow[t]{2}{*}{ Middle East } & $-0.491^{\star *}$ & $1.436^{\star \star \star}$ & 0.591 & 0.389 & $-0.449 * \star \star$ & $1.666^{\star \star \star}$ & $1.809 * \star \star$ & $0.783^{\star \star \star *}$ \\
\hline & [0.225] & [0.403] & [0.739] & [0.402] & [0.101] & [0.451] & [0.655] & [0.247] \\
\hline \multirow[t]{2}{*}{ Africa } & 0.025 & 1.028 & $1.958^{\star *}$ & $2.088^{\star \star \star}$ & $1.016^{\star \star \star}$ & $2.099 * \star *$ & $1.954^{\star \star \star}$ & $1.856^{\star \star \star}$ \\
\hline & [0.161] & [0.694] & [0.915] & [0.395] & [0.069] & [0.384] & [0.495] & {$[0.340]$} \\
\hline \multirow[t]{2}{*}{ Oceania \& Japan } & $0.743^{\star * \star}$ & 0.317 & 0.163 & $0.913^{* * *}$ & $1.428^{* \star *}$ & $1.825^{\star * \star}$ & $1.758^{* * *}$ & $1.500^{\star * * *}$ \\
\hline & [0.088] & {$[0.264]$} & [0.198] & {$[0.201]$} & [0.048] & {$[0.480]$} & {$[0.302]$} & {$[0.249]$} \\
\hline \multirow[t]{2}{*}{ Other } & $-1.546^{* \star *}$ & 0.174 & $0.797^{* \star}$ & $-1.555^{\star \star *}$ & 0.965 & 0.213 & -0.621 & $2.155^{\star \star \star}$ \\
\hline & [0.204] & [0.318] & {$[0.361]$} & [0.343] & [2.506] & [1.018] & [0.588] & [0.408] \\
\hline Observations & 106922 & 93046 & 93091 & 93038 & 322845 & 253357 & 247716 & 258260 \\
\hline $\mathrm{R}^{2}$ & 0.1723 & 0.0241 & 0.0227 & 0.0285 & 0.1204 & 0.0834 & 0.0824 & 0.0939 \\
\hline
\end{tabular}

Source: US: 1998-2004 CPS; Canada: 2001 Census.

Notes: Robust standard errors in brackets. ${ }^{*}$ significant at 10\%; $* \star 5 \%$; $* \star * 1 \%$ Each regression also includes a fourth order polynomial in age. Regressions for the US also include six year indicators reflecting the underlying merged set of CPS samples. 
Table 10 - Counterfactual Years of Schooling for Second Generation

Panel A. Current Schooling Differential

\begin{tabular}{|c|c|c|c|c|c|c|c|c|c|}
\hline & \multicolumn{4}{|c|}{ Second Generation } & \multirow{2}{*}{$\begin{array}{c}\text { Third Generation } \\
\text { Native Born } \\
\text { non-vismin }\end{array}$} & \multicolumn{4}{|c|}{ Yrs Schl(2nd) - Yrs Schl(3rd) } \\
\hline & $\begin{array}{r}\text { Father } \\
\text { only }\end{array}$ & $\begin{array}{r}\text { Mother } \\
\text { only }\end{array}$ & Both & Total & & $\begin{array}{r}\text { Father } \\
\text { only }\end{array}$ & $\begin{array}{r}\text { Mother } \\
\text { only }\end{array}$ & Both & Total \\
\hline \multicolumn{10}{|l|}{ Males } \\
\hline US & 14.09 & 13.93 & 13.86 & 13.96 & 13.70 & 0.39 & 0.23 & 0.16 & 0.26 \\
\hline Canada & 13.77 & 13.93 & 14.40 & 14.11 & 13.13 & 0.64 & 0.80 & 1.27 & 0.98 \\
\hline \multicolumn{10}{|l|}{ Females } \\
\hline US & 13.75 & 13.83 & 13.60 & 13.72 & 13.65 & 0.10 & 0.18 & -0.05 & 0.07 \\
\hline Canada & 13.75 & 13.86 & 14.45 & 14.11 & 13.23 & 0.52 & 0.63 & 1.22 & 0.88 \\
\hline
\end{tabular}

Panel B. Counterfactual Schooling Differential

\begin{tabular}{|c|c|c|c|c|c|c|c|c|c|}
\hline & \multicolumn{4}{|c|}{ Second Generation } & \multirow{2}{*}{$\begin{array}{c}\text { Third Generation } \\
\begin{array}{c}\text { Native Born } \\
\text { non-vismin }\end{array}\end{array}$} & \multicolumn{4}{|c|}{ Yrs Schl(2nd) - Yrs Schl(3rd) } \\
\hline & $\begin{array}{r}\text { Father } \\
\text { only }\end{array}$ & $\begin{array}{r}\text { Mother } \\
\text { only }\end{array}$ & Both & Total & & $\begin{array}{r}\text { Father } \\
\text { only }\end{array}$ & $\begin{array}{r}\text { Mother } \\
\text { only }\end{array}$ & Both & Total \\
\hline \multicolumn{10}{|l|}{ Males } \\
\hline US & 13.77 & 13.56 & 13.91 & 13.79 & 13.70 & 0.07 & -0.14 & 0.21 & 0.09 \\
\hline Canada & 14.27 & 14.69 & 14.99 & 14.79 & 13.13 & 1.14 & 1.56 & 1.86 & 1.66 \\
\hline \multicolumn{10}{|l|}{ Females } \\
\hline US & 13.31 & 13.65 & 13.55 & 13.49 & 13.65 & -0.34 & 0.00 & -0.10 & -0.16 \\
\hline Canada & 14.01 & 14.57 & 14.88 & 14.70 & 13.23 & 0.78 & 1.34 & 1.65 & 1.47 \\
\hline
\end{tabular}

Source: US: 1998-2004 CPS; Canada: 2001 Census. 
Table 11 A - Earnings differences across generations and visible minorities, Males

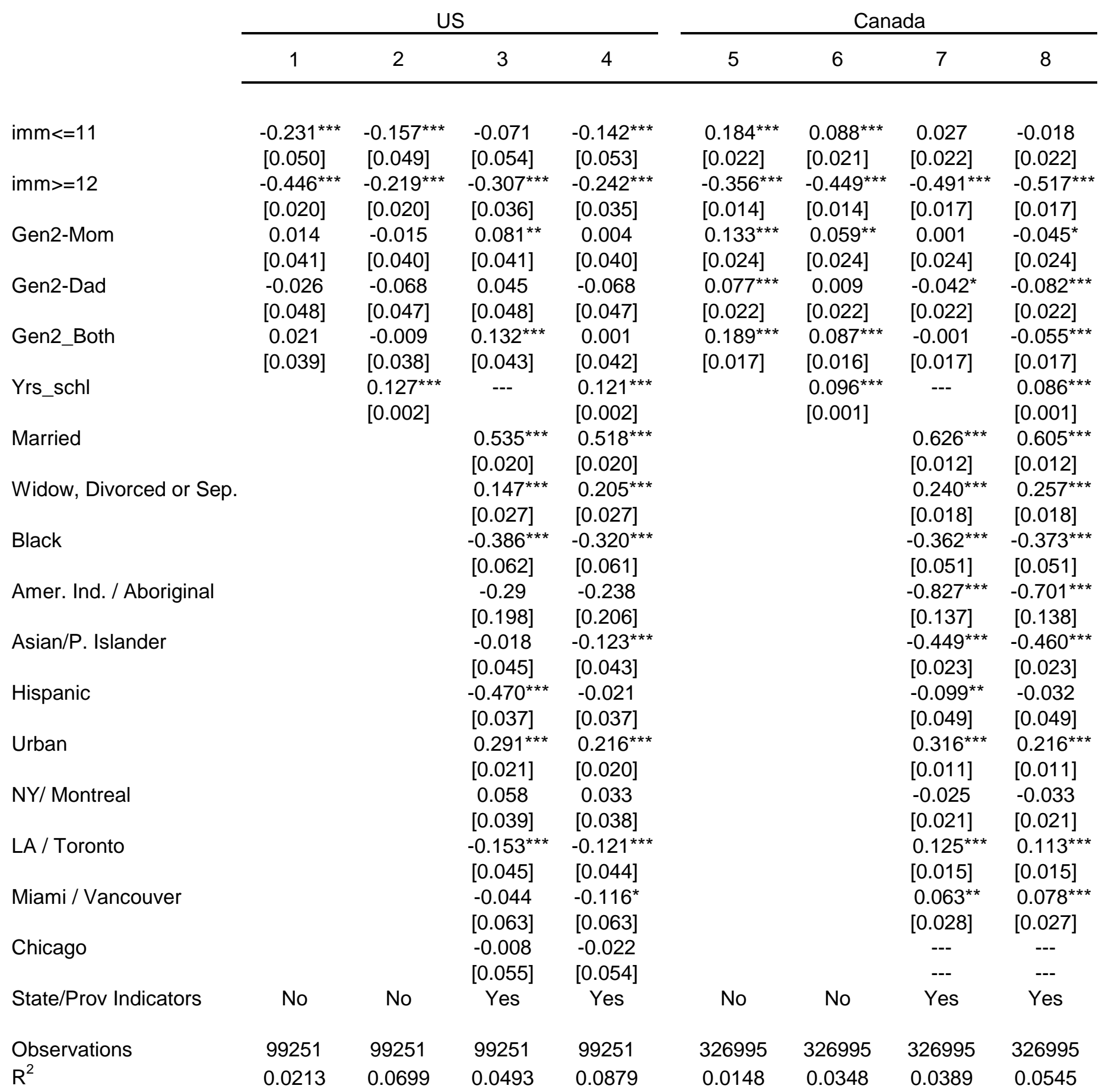

Source: US: 1998-2004 CPS; Canada: 2001 Census.

Notes: Robust standard errors in brackets. * significant at 10\%; ** $5 \%$; *** $1 \%$

Each regression also includes a fourth order polynomial in age. Regressions for the US also include six year indicators reflecting the underlying merged set of CPS samples. 
Table 11 B - Earnings differences across generations and visible minorities, Females

\begin{tabular}{lllllllllll}
\multicolumn{1}{c}{} & US & \multicolumn{5}{c}{ Canada } \\
\cline { 1 - 7 } \cline { 5 - 8 } & 2 & 3 & 4 & & 5 & 6 & 7 & 8 \\
\hline
\end{tabular}

\begin{tabular}{|c|c|c|c|c|c|c|c|c|}
\hline $\mathrm{imm}<=11$ & $\begin{array}{l}-0.029 \\
{[0.062]}\end{array}$ & $\begin{array}{c}0.031 \\
{[0.061]}\end{array}$ & $\begin{array}{l}-0.009 \\
{[0.069]}\end{array}$ & $\begin{array}{c}-0.071 \\
{[0.068]}\end{array}$ & $\begin{array}{l}0.231^{* * *} \\
{[0.025]}\end{array}$ & $\begin{array}{l}0.156^{\star \star *} \\
{[0.024]}\end{array}$ & $\begin{array}{c}0.037 \\
{[0.025]}\end{array}$ & $\begin{array}{c}0.001 \\
{[0.025]}\end{array}$ \\
\hline $\mathrm{imm}>=12$ & $\begin{array}{l}-0.518^{\star \star \star} \\
{[0.030]}\end{array}$ & $\begin{array}{l}-0.273^{\star \star \star} \\
{[0.029]}\end{array}$ & $\begin{array}{l}-0.502^{\star \star \star} \\
{[0.044]}\end{array}$ & $\begin{array}{l}-0.387^{\star * *} \\
{[0.043]}\end{array}$ & $\begin{array}{l}-0.325^{\star \star \star} \\
{[0.015]}\end{array}$ & $\begin{array}{l}-0.359 * * \star \\
{[0.015]}\end{array}$ & $\begin{array}{l}-0.506^{\star \star \star} \\
{[0.019]}\end{array}$ & $\begin{array}{l}-0.505^{\star \star \star} \\
{[0.019]}\end{array}$ \\
\hline Gen2-Mom & $\begin{array}{c}0.077 \\
{[0.048]}\end{array}$ & $\begin{array}{c}0.055 \\
{[0.047]}\end{array}$ & $\begin{array}{l}0.083^{\star} \\
{[0.048]}\end{array}$ & $\begin{array}{c}0.006 \\
{[0.047]}\end{array}$ & $\begin{array}{l}0.095^{\star * *} \\
{[0.027]}\end{array}$ & $\begin{array}{c}0.021 \\
{[0.026]}\end{array}$ & $\begin{array}{l}-0.021 \\
{[0.027]}\end{array}$ & $\begin{array}{l}-0.073^{* * *} \\
{[0.026]}\end{array}$ \\
\hline Gen2-Dad & $\begin{array}{c}0.023 \\
{[0.054]}\end{array}$ & $\begin{array}{l}-0.019 \\
{[0.053]}\end{array}$ & $\begin{array}{c}0.032 \\
{[0.056]}\end{array}$ & $\begin{array}{c}-0.072 \\
{[0.055]}\end{array}$ & $\begin{array}{l}0.110^{\star \star \star} \\
{[0.022]}\end{array}$ & $\begin{array}{c}0.039^{\star} \\
{[0.022]}\end{array}$ & $\begin{array}{c}-0.006 \\
{[0.022]}\end{array}$ & $\begin{array}{l}-0.055^{\star \star} \\
{[0.022]}\end{array}$ \\
\hline Gen2_Both & $\begin{array}{c}0.088^{*} \\
{[0.049]}\end{array}$ & $\begin{array}{c}0.077 \\
{[0.048]}\end{array}$ & $\begin{array}{c}0.095^{\star} \\
{[0.053]}\end{array}$ & $\begin{array}{l}-0.026 \\
{[0.052]}\end{array}$ & $\begin{array}{l}0.299 \star \star \star \\
{[0.018]}\end{array}$ & $\begin{array}{l}0.186^{\star \star \star} \\
{[0.018]}\end{array}$ & $\begin{array}{l}0.085^{\star \star \star} \\
{[0.018]}\end{array}$ & $\begin{array}{c}0.016 \\
{[0.018]}\end{array}$ \\
\hline Yrs_schl & & $\begin{array}{l}0.157^{\star * \star} \\
{[0.003]}\end{array}$ & -- & $\begin{array}{l}0.151^{\star \star \star} \\
{[0.003]}\end{array}$ & & $\begin{array}{l}0.134^{\star \star \star} \\
{[0.002]}\end{array}$ & --- & $\begin{array}{l}0.124^{\star \star \star} \\
{[0.002]}\end{array}$ \\
\hline Married & & & $\begin{array}{l}-0.382^{\star * *} \\
{[0.023]}\end{array}$ & $\begin{array}{l}-0.335^{\star \star *} \\
{[0.022]}\end{array}$ & & & $\begin{array}{l}-0.068^{\star \star *} \\
{[0.014]}\end{array}$ & $\begin{array}{l}-0.012 \\
{[0.013]}\end{array}$ \\
\hline Widow, Divorced or Sep. & & & $\begin{array}{l}-0.188^{\star * \star} \\
{[0.027]}\end{array}$ & $\begin{array}{l}-0.074^{* * *} \\
{[0.026]}\end{array}$ & & & $\begin{array}{l}-0.215^{\star \star \star} \\
{[0.018]}\end{array}$ & $\begin{array}{l}-0.130^{* \star \star *} \\
{[0.018]}\end{array}$ \\
\hline Black & & & $\begin{array}{l}-0.098 \\
{[0.075]}\end{array}$ & $\begin{array}{l}-0.006 \\
{[0.073]}\end{array}$ & & & $\begin{array}{l}-0.306^{\star * *} \\
{[0.056]}\end{array}$ & $\begin{array}{l}-0.300 * * \star \\
{[0.055]}\end{array}$ \\
\hline Amer. Ind. / Aboriginal & & & $\begin{array}{l}-0.495 \\
{[0.309]}\end{array}$ & $\begin{array}{c}-0.42 \\
{[0.313]}\end{array}$ & & & $\begin{array}{l}-0.566^{\star \star \star} \\
{[0.122]}\end{array}$ & $\begin{array}{l}-0.471^{\star * \star} \\
{[0.120]}\end{array}$ \\
\hline Asian/P. Islander & & & $\begin{array}{l}0.212^{* * *} \\
{[0.057]}\end{array}$ & $\begin{array}{c}0.139^{* *} \\
{[0.056]}\end{array}$ & & & $\begin{array}{l}-0.217^{\star \star \star} \\
{[0.024]}\end{array}$ & $\begin{array}{l}-0.190^{* \star *} \\
{[0.024]}\end{array}$ \\
\hline Hispanic & & & $\begin{array}{l}-0.462^{\star \star \star} \\
{[0.049]}\end{array}$ & $\begin{array}{l}-0.021 \\
{[0.049]}\end{array}$ & & & $\begin{array}{l}-0.149^{\star \star \star} \\
{[0.056]}\end{array}$ & $\begin{array}{l}-0.071 \\
{[0.056]}\end{array}$ \\
\hline Urban & & & $\begin{array}{l}0.309 * * * \\
{[0.026]}\end{array}$ & $\begin{array}{l}0.238^{\star \star \star} \\
{[0.026]}\end{array}$ & & & $\begin{array}{l}0.434^{\star \star \star} \\
{[0.013]}\end{array}$ & $\begin{array}{l}0.336^{\star \star \star} \\
{[0.012]}\end{array}$ \\
\hline NY/ Montreal & & & $\begin{array}{c}0.006 \\
{[0.049]}\end{array}$ & $\begin{array}{l}-0.046 \\
{[0.048]}\end{array}$ & & & $\begin{array}{l}0.079 * * * \\
{[0.022]}\end{array}$ & $\begin{array}{l}0.072^{\star * *} \\
{[0.022]}\end{array}$ \\
\hline LA / Toronto & & & $\begin{array}{l}-0.181^{\star * \star} \\
{[0.060]}\end{array}$ & $\begin{array}{l}-0.137^{\star *} \\
{[0.060]}\end{array}$ & & & $\begin{array}{l}0.202^{\star \star \star} \\
{[0.017]}\end{array}$ & $\begin{array}{l}0.180 * * * \\
{[0.017]}\end{array}$ \\
\hline Miami / Vancouver & & & $\begin{array}{l}-0.157^{\star} \\
{[0.088]}\end{array}$ & $\begin{array}{l}-0.244^{\star \star \star} \\
{[0.086]}\end{array}$ & & & $\begin{array}{l}0.095^{\star \star \star} \\
{[0.030]}\end{array}$ & $\begin{array}{l}0.091 * * * \\
{[0.030]}\end{array}$ \\
\hline Chicago & & & $\begin{array}{l}-0.129^{\star} \\
{[0.069]}\end{array}$ & $\begin{array}{c}-0.169 * * \\
{[0.068]}\end{array}$ & & & $\begin{array}{l}--- \\
---\end{array}$ & --- \\
\hline State/Prov Indicators & No & No & Yes & Yes & No & No & Yes & Yes \\
\hline $\begin{array}{l}\text { Observations } \\
R^{2}\end{array}$ & 90052 & $\begin{array}{l}90052 \\
00524\end{array}$ & $\begin{array}{l}90052 \\
0028\end{array}$ & 90052 & $\begin{array}{c}298241 \\
0011\end{array}$ & $\begin{array}{l}298241 \\
00406\end{array}$ & $\begin{array}{l}298241 \\
00253\end{array}$ & $\begin{array}{l}298241 \\
00499\end{array}$ \\
\hline
\end{tabular}

Source: US: 1998-2004 CPS; Canada: 2001 Census.

Notes: Robust standard errors in brackets. * significant at 10\%; ** $5 \%$; $* \star * 1 \%$

Each regression also includes a fourth order polynomial in age. Regressions for the US also include six year indicators reflecting the underlying merged set of CPS samples. 
Table 12 A - Earnings Outcomes, Returns to human capital characteristics, Males

\begin{tabular}{|c|c|c|c|c|c|c|}
\hline & \multicolumn{3}{|c|}{ US } & \multicolumn{3}{|c|}{ Canada } \\
\hline & 1 & 2 & 3 & 4 & 5 & 6 \\
\hline Immigrant & $\begin{array}{l}-0.271^{\star \star *} \\
{[0.021]}\end{array}$ & $\begin{array}{l}0.263^{\star *} \\
{[0.115]}\end{array}$ & $\begin{array}{c}-0.03 \\
{[0.108]}\end{array}$ & $\begin{array}{l}-0.533^{\star \star *} \\
{[0.013]}\end{array}$ & $\begin{array}{l}-0.022 \\
{[0.080]}\end{array}$ & $\begin{array}{c}-0.114 \\
{[0.073]}\end{array}$ \\
\hline Second Generation & $\begin{array}{l}-0.075^{\star \star \star} \\
{[0.025]}\end{array}$ & $\begin{array}{c}0.104 \\
{[0.164]}\end{array}$ & $\begin{array}{c}0.036 \\
{[0.164]}\end{array}$ & $\begin{array}{l}-0.087^{\star * \star} \\
{[0.013]}\end{array}$ & $\begin{array}{l}-0.126 \\
{[0.089]}\end{array}$ & $\begin{array}{c}-0.204^{\star *} \\
{[0.089]}\end{array}$ \\
\hline Experience (Exp) & $\begin{array}{l}0.046^{\star \star \star} \\
{[0.002]}\end{array}$ & $\begin{array}{l}0.051^{\star \star *} \\
{[0.003]}\end{array}$ & $\begin{array}{l}0.041^{\star \star \star} \\
{[0.003]}\end{array}$ & $\begin{array}{l}0.051^{\star \star \star} \\
{[0.002}\end{array}$ & $\begin{array}{l}0.050 \star \star \star \\
{[0.002]}\end{array}$ & $\begin{array}{l}0.036 \text { *** } \\
{[0.002}\end{array}$ \\
\hline Experience $^{2}\left(\right.$ Exp $\left.^{2}\right)$ & $\begin{array}{l}-0.001^{\star \star \star} \\
{[0.000]}\end{array}$ & $\begin{array}{l}-0.001^{\star \star *} \\
{[0.000]}\end{array}$ & $\begin{array}{l}-0.001^{\star \star \star} \\
{[0.000]}\end{array}$ & $\begin{array}{l}-0.001^{\star \star \star} \\
{[0.000]}\end{array}$ & $\begin{array}{l}-0.001^{\star \star \star} \\
{[0.000]}\end{array}$ & $\begin{array}{l}-0.001^{\star \star \star} \\
{[0.000]}\end{array}$ \\
\hline Yrs of School & $\begin{array}{l}0.123^{\star * \star} \\
{[0.002]}\end{array}$ & $\begin{array}{l}0.140 \star \star \star \\
{[0.003]}\end{array}$ & $\begin{array}{l}0.141^{\star \star \star} \\
{[0.003]}\end{array}$ & $\begin{array}{l}0.092^{\star * *} \\
{[0.002]}\end{array}$ & $\begin{array}{l}0.112^{\star \star \star} \\
{[0.002]}\end{array}$ & $\begin{array}{l}0.115^{\star \star \star} \\
{[0.002]}\end{array}$ \\
\hline Urban & $\begin{array}{l}0.199 * \star \star \\
{[0.020]}\end{array}$ & $\begin{array}{l}0.197^{\star \star \star} \\
{[0.020]}\end{array}$ & $\begin{array}{l}0.202^{\star \star \star} \\
{[0.020]}\end{array}$ & $\begin{array}{l}0.190 \star \star \star \\
{[0.011]}\end{array}$ & $\begin{array}{l}0.165^{\star \star \star} \\
{[0.012]}\end{array}$ & $\begin{array}{l}0.168^{\star \star \star} \\
{[0.011]}\end{array}$ \\
\hline NY/ Montreal & $\begin{array}{c}0.012 \\
{[0.038]}\end{array}$ & $\begin{array}{c}0.005 \\
{[0.038]}\end{array}$ & $\begin{array}{c}0.001 \\
{[0.038]}\end{array}$ & $\begin{array}{c}-0.028 \\
{[0.021]}\end{array}$ & $\begin{array}{l}-0.041^{\star *} \\
{[0.021]}\end{array}$ & $\begin{array}{c}-0.03 \\
{[0.021]}\end{array}$ \\
\hline LA / Toronto & $\begin{array}{l}-0.104^{\star \star} \\
{[0.044]}\end{array}$ & $\begin{array}{l}-0.108^{\star *} \\
{[0.044]}\end{array}$ & $\begin{array}{l}-0.131^{\star \star \star} \\
{[0.044]}\end{array}$ & $\begin{array}{l}0.031^{\star *} \\
{[0.015]}\end{array}$ & $\begin{array}{c}0.035^{\star *} \\
{[0.015]}\end{array}$ & $\begin{array}{l}0.091^{\star * \star} \\
{[0.015]}\end{array}$ \\
\hline Miami / Vancouver & $\begin{array}{l}-0.117^{*} \\
{[0.063]}\end{array}$ & $\begin{array}{l}-0.132^{\star *} \\
{[0.063]}\end{array}$ & $\begin{array}{l}-0.132^{\star *} \\
{[0.062]}\end{array}$ & $\begin{array}{c}-0.008 \\
{[0.028]}\end{array}$ & $\begin{array}{c}0.008 \\
{[0.028]}\end{array}$ & $\begin{array}{l}0.070^{\star *} \\
{[0.028]}\end{array}$ \\
\hline Chicago & $\begin{array}{l}-0.017 \\
{[0.055]}\end{array}$ & $\begin{array}{l}-0.031 \\
{[0.055]}\end{array}$ & $\begin{array}{c}-0.04 \\
{[0.055]}\end{array}$ & --- & --- & --- \\
\hline expimmig & & $\begin{array}{l}-0.019 * * * \\
{[0.007]}\end{array}$ & -- & & $\begin{array}{l}-0.001 \\
{[0.004]}\end{array}$ & --- \\
\hline exp2*immig & & $\begin{array}{l}0.001^{\star \star *} \\
{[0.000]}\end{array}$ & --- & & $\begin{array}{l}0.000 * \star * \\
{[0.000]}\end{array}$ & --- \\
\hline exp*gen2 & & $\begin{array}{c}0.002 \\
{[0.009]}\end{array}$ & $\begin{array}{c}0.012 \\
{[0.009]}\end{array}$ & & $\begin{array}{l}0.030 \text { *** } \\
{[0.004]}\end{array}$ & $\begin{array}{l}0.045^{\star \star \star} \\
{[0.004]}\end{array}$ \\
\hline exp2*gen2 & & $\begin{array}{c}0.000 \\
{[0.000]}\end{array}$ & $\begin{array}{c}0.000 \\
{[0.000]}\end{array}$ & & $\begin{array}{l}-0.001^{\star \star \star} \\
{[0.000]}\end{array}$ & $\begin{array}{l}-0.001^{\star \star \star} \\
{[0.000]}\end{array}$ \\
\hline yrs_schl*immig & & $\begin{array}{l}-0.036^{\star \star \star} \\
{[0.005]}\end{array}$ & --- & & $\begin{array}{l}-0.051^{\star \star \star} \\
{[0.004]}\end{array}$ & --- \\
\hline yrs_schl*gen2 & & $\begin{array}{l}-0.014 \\
{[0.009]}\end{array}$ & $\begin{array}{l}-0.015^{\star} \\
{[0.009]}\end{array}$ & & $\begin{array}{l}-0.013^{\star * *} \\
{[0.005]}\end{array}$ & $\begin{array}{l}-0.017^{\star * * *} \\
{[0.005]}\end{array}$ \\
\hline exp_foreign*immig & & & $\begin{array}{l}-0.013^{\star \star} \\
{[0.006]}\end{array}$ & & & $\begin{array}{l}-0.046^{\star \star \star} \\
{[0.004]}\end{array}$ \\
\hline exp_foreign2*immig & & & $\begin{array}{c}0.000 \\
{[0.000]}\end{array}$ & & & $\begin{array}{l}0.001^{\star * *} \\
{[0.000]}\end{array}$ \\
\hline exp_host_country*immig & & & $\begin{array}{l}0.048^{\star \star \star} \\
{[0.007]}\end{array}$ & & & $\begin{array}{l}0.112^{\star \star \star} \\
{[0.004]}\end{array}$ \\
\hline exp_host_country2*immig & & & $\begin{array}{l}-0.001^{* * *} \\
{[0.000]}\end{array}$ & & & $\begin{array}{l}-0.002^{\star * *} \\
{[0.000]}\end{array}$ \\
\hline yrs_schl_foreign*immig & & & $\begin{array}{l}-0.046^{\star * *} \\
{[0.005]}\end{array}$ & & & $\begin{array}{l}-0.075^{\star * *} \\
{[0.004]}\end{array}$ \\
\hline yrs_schl_host_country*immig & & & $\begin{array}{l}-0.037^{* * *} \\
{[0.007]}\end{array}$ & & & $\begin{array}{l}-0.067^{\star * *} \\
{[0.004]}\end{array}$ \\
\hline State/Prov Indicators & Yes & Yes & Yes & Yes & Yes & Yes \\
\hline Observations & 99251 & 99251 & 99251 & 326995 & 326995 & 326995 \\
\hline $\mathrm{R}^{2}$ & 0.0708 & 0.073 & 0.0752 & 0.0359 & 0.0395 & 0.052 \\
\hline
\end{tabular}

Source: US: 1998-2004 CPS; Canada: 2001 Census.

Notes: Robust standard errors in brackets. ${ }^{*}$ significant at $10 \%$; $* \star 5 \%$; $* \star \star 1 \%$. Regressions for the US also include six year indicators reflecting the underlying merged set of CPS samples. 
Table 12 B - Earnings Outcomes, Returns to human capital characteristics, Females

\begin{tabular}{|c|c|c|c|c|c|c|}
\hline & \multicolumn{3}{|c|}{ US } & \multicolumn{3}{|c|}{ Canada } \\
\hline & 1 & 2 & 3 & 4 & 5 & 6 \\
\hline Immigrant & $\begin{array}{l}-0.321^{\star \star *} \\
{[0.029]}\end{array}$ & $\begin{array}{c}0.198 \\
{[0.168]}\end{array}$ & $\begin{array}{l}-0.104 \\
{[0.161]}\end{array}$ & $\begin{array}{l}-0.506^{\star \star *} \\
{[0.014]}\end{array}$ & $\begin{array}{c}0.072 \\
{[0.091]}\end{array}$ & $\begin{array}{c}0.114 \\
{[0.085]}\end{array}$ \\
\hline Second Generation & $\begin{array}{c}-0.03 \\
{[0.030]}\end{array}$ & $\begin{array}{c}0.237 \\
{[0.221]}\end{array}$ & $\begin{array}{c}0.179 \\
{[0.221]}\end{array}$ & $\begin{array}{l}-0.053^{\star * *} \\
{[0.014]}\end{array}$ & $\begin{array}{l}0.603^{\star \star \star} \\
{[0.107]}\end{array}$ & $\begin{array}{l}0.550^{* * *} \\
{[0.107]}\end{array}$ \\
\hline Experience (Exp) & $\begin{array}{l}0.018^{* * *} \\
{[0.003]}\end{array}$ & $\begin{array}{l}0.024^{\star * *} \\
{[0.003]}\end{array}$ & $\begin{array}{l}0.016^{\star * \star} \\
{[0.003]}\end{array}$ & $\begin{array}{l}0.043^{\star * *} \\
{[0.002]}\end{array}$ & $\begin{array}{l}0.047^{\star \star *} \\
{[0.002]}\end{array}$ & $\begin{array}{l}0.035^{\star * *} \\
{[0.002]}\end{array}$ \\
\hline Experience $^{2}\left(\right.$ Exp $\left.^{2}\right)$ & $\begin{array}{l}-0.000^{\star \star \star} \\
{[0.000]}\end{array}$ & $\begin{array}{l}-0.000^{\star * *} \\
{[0.000]}\end{array}$ & $\begin{array}{l}-0.000^{\star \star *} \\
{[0.000]}\end{array}$ & $\begin{array}{l}-0.001^{\star * \star} \\
{[0.000]}\end{array}$ & $\begin{array}{l}-0.001^{\star \star \star} \\
{[0.000]}\end{array}$ & $\begin{array}{l}-0.001^{\star \star \star} \\
{[0.000]}\end{array}$ \\
\hline Yrs of School & $\begin{array}{l}0.158^{\star * *} \\
{[0.003]}\end{array}$ & $\begin{array}{l}0.174^{\star \star *} \\
{[0.004]}\end{array}$ & $\begin{array}{l}0.174^{* * *} \\
{[0.004]}\end{array}$ & $\begin{array}{l}0.136^{\star \star *} \\
{[0.002]}\end{array}$ & $\begin{array}{l}0.165^{\star \star \star} \\
{[0.002]}\end{array}$ & $\begin{array}{l}0.167^{\star * *} \\
{[0.002]}\end{array}$ \\
\hline Urban & $\begin{array}{l}0.250 \star \star \star \\
{[0.026]}\end{array}$ & $\begin{array}{l}0.250 \star \star \star \\
{[0.026]}\end{array}$ & $\begin{array}{l}0.253^{\star \star *} \\
{[0.026]}\end{array}$ & $\begin{array}{l}0.331^{\star \star \star} \\
{[0.012]}\end{array}$ & $\begin{array}{l}0.309 * \star \star \\
{[0.012]}\end{array}$ & $\begin{array}{l}0.314^{\star \star \star} \\
{[0.012]}\end{array}$ \\
\hline NY/ Montreal & $\begin{array}{l}-0.048 \\
{[0.047]}\end{array}$ & $\begin{array}{c}-0.053 \\
{[0.047]}\end{array}$ & $\begin{array}{l}-0.057 \\
{[0.047]}\end{array}$ & $\begin{array}{l}0.061^{* * *} \\
{[0.022]}\end{array}$ & $\begin{array}{l}0.051^{\star *} \\
{[0.022]}\end{array}$ & $\begin{array}{l}0.054^{\star *} \\
{[0.022]}\end{array}$ \\
\hline LA / Toronto & $\begin{array}{l}-0.151^{* *} \\
{[0.060]}\end{array}$ & $\begin{array}{l}-0.157^{\star \star \star} \\
{[0.060]}\end{array}$ & $\begin{array}{l}-0.174^{\star \star \star} \\
{[0.060]}\end{array}$ & $\begin{array}{l}0.146^{\star \star \star} \\
{[0.016]}\end{array}$ & $\begin{array}{l}0.149 * \star * \\
{[0.016]}\end{array}$ & $\begin{array}{l}0.196^{\star \star \star} \\
{[0.016]}\end{array}$ \\
\hline Miami / Vancouver & $\begin{array}{l}-0.255^{\star \star \star} \\
{[0.086]}\end{array}$ & $\begin{array}{l}-0.261^{* * *} \\
{[0.086]}\end{array}$ & $\begin{array}{l}-0.259 * \star * \\
{[0.085]}\end{array}$ & $\begin{array}{l}0.061^{\star *} \\
{[0.030]}\end{array}$ & $\begin{array}{c}0.073^{* *} \\
{[0.030]}\end{array}$ & $\begin{array}{l}0.130 * \star \star \\
{[0.029]}\end{array}$ \\
\hline Chicago & $\begin{array}{l}-0.160 * \star \\
{[0.068]}\end{array}$ & $\begin{array}{l}-0.171^{\star *} \\
{[0.068]}\end{array}$ & $\begin{array}{l}-0.175^{\star \star} \\
{[0.068]}\end{array}$ & --- & --- & --- \\
\hline exp*immig & & $\begin{array}{l}-0.020^{* *} \\
{[0.009]}\end{array}$ & --- & & $\begin{array}{l}0.010 * * \\
{[0.005]}\end{array}$ & --- \\
\hline exp2*immig & & $\begin{array}{l}0.001^{\star \star \star} \\
{[0.000]}\end{array}$ & --- & & $\begin{array}{c}0.000 \\
{[0.000]}\end{array}$ & --- \\
\hline exp*gen2 & & $\begin{array}{l}-0.009 \\
{[0.010]}\end{array}$ & $\begin{array}{l}-0.001 \\
{[0.010]}\end{array}$ & & $\begin{array}{c}0.000 \\
{[0.004]}\end{array}$ & $\begin{array}{l}0.012^{\star * *} \\
{[0.004]}\end{array}$ \\
\hline exp2*gen2 & & $\begin{array}{c}0.000 \\
{[0.000]}\end{array}$ & $\begin{array}{c}0.000 \\
{[0.000]}\end{array}$ & & $\begin{array}{l}-0.000^{\star \star} \\
{[0.000]}\end{array}$ & $\begin{array}{l}-0.001^{\star \star \star} \\
{[0.000]}\end{array}$ \\
\hline yrs_schl*immig & & $\begin{array}{l}-0.035^{\star \star \star} \\
{[0.008]}\end{array}$ & --- & & $\begin{array}{l}-0.064^{\star \star \star} \\
{[0.004]}\end{array}$ & -- \\
\hline yrs_schl*gen2 & & $\begin{array}{l}-0.012 \\
{[0.013]}\end{array}$ & $\begin{array}{l}-0.013 \\
{[0.013]}\end{array}$ & & $\begin{array}{l}-0.038^{* \star *} \\
{[0.006]}\end{array}$ & $\begin{array}{l}-0.041^{\star * *} \\
{[0.006]}\end{array}$ \\
\hline exp_foreign*immig & & & $\begin{array}{l}-0.029^{\star \star \star} \\
{[0.008]}\end{array}$ & & & $\begin{array}{l}-0.048^{\star \star \star} \\
{[0.004]}\end{array}$ \\
\hline exp_foreign2*immig & & & $\begin{array}{l}0.001^{* * *} \\
{[0.000]}\end{array}$ & & & $\begin{array}{l}0.001^{\star \star \star} \\
{[0.000]}\end{array}$ \\
\hline exp_host_country*immig & & & $\begin{array}{l}0.060^{\star \star *} \\
{[0.009]}\end{array}$ & & & $\begin{array}{l}0.111^{* * *} \\
{[0.004]}\end{array}$ \\
\hline exp_host_country2*immig & & & $\begin{array}{l}-0.001^{* * *} \\
{[0.000]}\end{array}$ & & & $\begin{array}{l}-0.002^{\star \star \star} \\
{[0.000]}\end{array}$ \\
\hline yrs_schl_foreign*immig & & & $\begin{array}{l}-0.049 * * \star \\
{[0.008]}\end{array}$ & & & $\begin{array}{l}-0.093^{\star \star \star} \\
{[0.004]}\end{array}$ \\
\hline yrs_schl_host_country*immig & & & $\begin{array}{l}-0.044^{\star \star \star} \\
{[0.010]}\end{array}$ & & & $\begin{array}{l}-0.075^{\star \star \star} \\
{[0.005]}\end{array}$ \\
\hline State/Prov Indicators & Yes & Yes & Yes & Yes & Yes & Yes \\
\hline Observations & 90052 & 90052 & 90052 & 298241 & 298241 & 298241 \\
\hline $\mathrm{R}^{2}$ & 0.0538 & 0.0552 & 0.057 & 0.0429 & 0.0468 & 0.0573 \\
\hline
\end{tabular}

Source: US: 1998-2004 CPS; Canada: 2001 Census.

Notes: Robust standard errors in brackets. * significant at 10\%; ** 5\%; *** 1\%. Regressions for the US also include six year indicators reflecting the underlying merged set of CPS samples. 